NBER WORKING PAPER SERIES

\title{
SHARING RISK WITH THE GOVERNMENT: HOW TAXES AFFECT CORPORATE RISK TAKING
}

\author{
Alexander Ljungqvist \\ Liandong Zhang \\ Luo Zuo \\ Working Paper 21834 \\ http://www.nber.org/papers/w21834 \\ NATIONAL BUREAU OF ECONOMIC RESEARCH \\ 1050 Massachusetts Avenue \\ Cambridge, MA 02138 \\ December 2015
}

Previously circulated as "Sharing Risk with the Government: On the Causal Effects of Taxes on Corporate Risk-Taking." We gratefully acknowledge helpful comments from two anonymous reviewers, Morten Bennedsen, Nathan Goldman, Abhiroop Mukherjee, and Stefan Zeume (our discussants), Eli Bartov, Sanjeev Bhojraj, Robert Bloomfield, Agnes Cheng, Robert Engle, Michelle Hanlon, Shane Heitzman, Sudarshan Jayaraman, Andrew Karolyi, Anne Marie Knott, Clive Lennox, Ji-Chai Lin, Kenneth Merkley, Jeffrey Ng, Joseph Piotroski, Mark Soliman, K.R. Subramanyam, Ross Watts, John Wei, Haibin Wu, Eric Yeung, Paul Zarowin, and Zilong Zhang, as well as participants at various seminars and conferences. We thank Charles Choi and Chuchu Liang for competent research assistance. Zuo gratefully acknowledges generous financial support from the Institute for the Social Sciences at Cornell University. The views expressed herein are those of the authors and do not necessarily reflect the views of the National Bureau of Economic Research.

NBER working papers are circulated for discussion and comment purposes. They have not been peer-reviewed or been subject to the review by the NBER Board of Directors that accompanies official NBER publications.

(C) 2015 by Alexander Ljungqvist, Liandong Zhang, and Luo Zuo. All rights reserved. Short sections of text, not to exceed two paragraphs, may be quoted without explicit permission provided that full credit, including $\odot$ notice, is given to the source. 
Sharing Risk with the Government: How Taxes Affect Corporate Risk Taking Alexander Ljungqvist, Liandong Zhang, and Luo Zuo

NBER Working Paper No. 21834

December 2015, Revised January 2017

JEL No. G32,H32

\section{ABSTRACT}

Using 113 staggered changes in corporate income tax rates across U.S. states, we provide evidence on how taxes affect corporate risk-taking decisions. Higher taxes reduce expected profits more for risky projects than for safe ones, as the government shares in a firm's upside but not in its downside. Consistent with this prediction, we find that risk taking is sensitive to taxes, albeit asymmetrically: the average firm reduces risk in response to a tax increase (primarily by changing its operating cycle and reducing R\&D risk) but does not respond to a tax cut. We trace the asymmetry back to constraints on risk taking imposed by creditors. Finally, tax loss-offset rules moderate firms' sensitivity to taxes by allowing firms to partly share downside risk with the government.

Alexander Ljungqvist

Stern School of Business

New York University

44 West Fourth Street, \#9-160

New York, NY 10012

and NBER

aljungqv@stern.nyu.edu

Liandong Zhang

College of Business

City University of Hong Kong

83 Tat Chee Avenue

Kowloon, Hong Kong

liandong.zhang@cityu.edu.hk
Luo Zuo

Johnson Graduate School of Management

Cornell University

114 East Avenue

349 Sage Hall

Ithaca, NY 14853

luozuo@cornell.edu 


\section{Introduction}

Taxation is one of the most important tools governments use to influence the economy. Taxes affect many aspects of economic activity, from individuals’ labor supply, consumption, and savings decisions to companies’ hiring, location, and capital investment choices. In this paper, we ask how taxes on corporate income affect corporate risk taking. As Solow (1956) notes, risk taking is essential for both firms and economies to grow in the long run.

Income taxes affect corporate risk taking because they induce an asymmetry in a firm’s payoffs. This basic insight can be traced back to early work on individuals' risk-taking choices in response to personal income taxes (Domar and Musgrave 1944; Feldstein 1969; Stiglitz 1969) and to subsequent applications to the corporate setting (Green and Talmor 1985). A simple numerical example serves to illustrate the intuition. Suppose there are two projects (A and B) and two equally likely outcomes (“good” and “bad”). Project A yields a profit of $\$ 40$ in both scenarios; project B yields a profit of $\$ 100$ in the good scenario but a loss of $\$ 20$ in the bad scenario. Project risk is idiosyncratic and hence diversifiable. Absent taxes, the expected profit of each project is $\$ 40$ and so a risk-neutral firm will be indifferent between the projects.

Now suppose the tax rate increases from zero to 30\%. This reduces the expected after-tax profit of both projects, but risky project B is more affected than safe project A: B's expected profit falls to $\$ 25$ while A’s falls to only $\$ 28 .^{1}$ The greater reduction (of $\$ 3$ ) in project B’s expected profit stems from the fact that the government shares in the profit but not in the loss. Given this asymmetry, a risk-neutral firm will now prefer the safe project to the risky project. ${ }^{2}$ Generalizing from the example, we predict that firms should respond to a tax increase by choosing safer projects and thereby reducing the risks they take.

\footnotetext{
${ }^{1}$ For project A, $\$ 40 \times(1-0.3)=\$ 28$; for project B, $0.5 \times[(1-0.3) \times \$ 100-\$ 20]=\$ 25$.

${ }^{2}$ Firms are commonly modeled as being risk-neutral, but this is not crucial to the argument.
} 
As Domar and Musgrave (1944) argue, introducing loss-offsets into the tax code can modify this prediction. Consider the extreme case in which losses can be completely written off against past or future profits. In this case, the pre-tax and post-tax ordering of the two projects are identical because both the upside and the downside are reduced at the same tax rate. ${ }^{3}$ In practice, the tax code permits at most a partial offset of losses, in which case the upside is reduced by more than the downside. A tax increase will then reduce the expected profit of the risky project by more than that of the safe project and firms should respond by reducing risk.

Absent other frictions, these arguments apply symmetrically to tax increases and tax cuts, so firms should respond to cuts by increasing risk. In practice, there is reason to expect asymmetry. As the literature on risk-shifting emphasizes, higher risk reduces the value of claims held by creditors. Whether a firm can respond to a tax cut by increasing risk then depends on the extent to which creditors constrain its behavior, e.g., by means of debt covenants. In the presence of such constraints, the effect of a tax cut on risk taking is likely attenuated for many firms.

A key challenge when testing how taxes affect corporate policies is that a firm's tax status is often endogenous to its policies. For example, a firm's choice of investment projects will affect its future marginal tax rate. The literature confronts this identification challenge in various ways. One approach is to exploit changes in federal income tax rates. Unfortunately, federal tax changes suffer from two shortcomings: they are few and far between, and they affect virtually all firms in the economy at the same time, making it difficult to find control firms with which to establish a plausible counterfactual. A second approach is to exploit cross-country differences in tax policies. This typically results in a larger number of tax "shocks" than in studies using federal tax changes, but often requires implausible assumptions about treated firms and their controls being comparable despite operating in different countries.

\footnotetext{
${ }^{3}$ In our numerical example, project B’s expected profit with full loss offsets is $\$ 28$, the same as A's.
} 
We adopt a third approach, pioneered by Asker, Farre-Mensa, and Ljungqvist (2015), Heider and Ljungqvist (2015), and Farre-Mensa and Ljungqvist (2016). The approach exploits the fact that U.S. companies pay not only federal income tax but also taxes in the various states in which they operate. As Heider and Ljungqvist note, state taxes are a meaningful part of U.S. firms’ overall tax burden, accounting for about $21 \%$ of total income taxes paid in Compustat. Changes in state corporate income tax rates are numerous (we count 113 between 1990 and 2011) and, because they are staggered across states and time, lend themselves to a differences-in-differences research design. As long as the usual identifying assumptions plausibly hold, such a design can disentangle the effects of tax changes from other macroeconomic shocks that affect firms' risk taking by establishing a counterfactual - what level of risk would firms have chosen absent the tax change? - using as controls firms that experience similar economic conditions (in time, space, and industry) but are not themselves subject to a tax change.

By way of preview, we have four main results. First, we find that firms respond to tax increases by reducing their earnings volatility, as expected. To illustrate, a treated firm reduces its earnings volatility by $2.6 \%$ in response to the average tax increase of 136 basis points, relative to other firms in the same industry that are not subject to a tax change in their headquarter state that year. ${ }^{4}$ This point estimate is likely conservative, given that firms are taxed not just in their home state but in every state in which they have operations (their so called "nexus" states). This means that a given state's tax change applies to less than a multi-state firm's entire tax base, so tests that ignore the geographic distribution of a firm's tax base likely understate the sensitivity of risk taking to corporate income taxes. To address this issue, we construct a measure of state tax changes that takes into account each firm's tax exposure to each state. Doing so yields tax

\footnotetext{
${ }^{4}$ This effect is estimated over the 3 years following a tax increase; it becomes stronger when we give firms more time to adjust their risk profiles. Over the 6 years following a tax increase, for example, the average treated firm reduces risk by a cumulative $4.8 \%$.
} 
sensitivities that are between $25 \%$ and $60 \%$ larger than our baseline estimates.

Second, investigating possible channels, we find that the main ways in which firms achieve these risk reductions are efforts to shorten their operating cycles (which puts less capital at risk, in particular in the form of inventories) and to find less risky ways to commercialize their R\&D projects. We find no evidence that firms tinker with their operating leverage, nor that they change the level of their capital expenditures or $\mathrm{R} \& \mathrm{D}$ spending in response to state tax changes.

Third, we find evidence consistent with an asymmetric tax sensitivity: firms do not, on average, respond significantly to tax cuts, especially on a nexus-weighted basis. This finding is consistent with our argument that firms face constraints on their ability to increase risk, for example, in the form of covenants imposed by their creditors. If so, we expect firms with low financial leverage to face fewer constraints and so to be more responsive to tax cuts. Consistent with this conjecture, we find that low-leverage firms increase risk in response to tax cuts (by 6-7\% for each percentage-point cut in taxes). High-leverage firms, on the other hand, do not.

Fourth, we find support for Domar and Musgrave's (1944) argument that the ability to offset losses against past or future profits should weaken the negative effect of income taxes on risk taking. To establish this result, we collect detailed information on how state tax loss carryback and carryforward rules have evolved over time. When we sort firms by their ability to offset tax losses, we find that the negative effect of tax increases on risk taking is largely driven by firms with a limited ability to offset losses. We also test how firms respond to the rule changes themselves using a diff-in-diff setup. Firms' responses to changes in offset rules broadly mirror their responses to changes in tax rates. In particular, they asymmetrically reduce risk when their ability to carry back losses is reduced.

A causal interpretation of our findings requires that the diff-in-diff identifying assumptions 
plausibly hold. Threats to identification in our setting principally come from three directions: a failure of the parallel-trends assumption, the possibility that local shocks trigger both states to change their tax rates and firms to adjust their risk taking, leading to a spurious correlation between tax and risk, and the potential for anticipation effects to bias the estimated tax sensitivities. We perform a battery of tests designed to investigate these identification challenges.

A standard dynamic test shows that treated and control firms exhibit similar trends in risk taking before the state tax rate changes, supporting the parallel-trends assumption. To remove potential confounding effects coming from unobserved changes in local economic conditions that diffuse across state borders, we restrict the sample of controls to firms in states neighboring treated firms' home states. This allows us to difference away unobserved confounding effects, assuming that economic conditions are similar in neighboring states while tax policies stop at the state's border. Our results are robust to this design. As for confounds whose effects coincide in time with the treatment and do not diffuse across state borders, we show that coincident policy changes (such as changes in state investment incentive programs) do not drive our results; moreover, an Altonji, Elder, and Taber (2005) type test suggests that selection on unobservables is not a major concern in our setting. Finally, we argue that changes in risk taking of the kind we identify in our setting are not reasonably subject to major adjustment costs, which lessens concerns that anticipation effects bias our estimates (Hennessy and Strebulaev 2015). Empirically, we find no evidence that firms change risk in anticipation of future tax changes.

Our study makes contributions to several literatures. First, it contributes to the tax literature and to the literature on the effects of taxes on corporate policies by documenting that firms finetune their risk profiles when their tax rates change and that they do so in a way that is consistent with the theoretical insights of Domar and Musgrave (1944), Feldstein (1969), and Stiglitz 
(1969). Prior work on the effects of taxes on corporate policies largely focuses on firms' capital structure (following Modigliani and Miller 1958) and investment choices (following Hall and Jorgenson 1967). The latter body of work is particularly relevant in our context. Its focus is on the effect of taxes on the level of investment. As Hines (1998) notes, this focus has met with little empirical success: “The apparent inability of tax incentives to stimulate aggregate investment spending is one of the major puzzles in the empirical investment literature” (p. 2). We extend this body of work by showing that corporate taxes affect firms' choice of risk taking.

Second, our study adds a new angle to the literature on corporate risk taking by identifying taxes as an important determinant. While prior work highlights many other determinants, tax has largely been ignored. ${ }^{5}$ A notable exception is a recent working paper by Langenmayr and Lester (2015) whose best identified evidence comes from a change in a rule governing tax loss-offsets affecting a limited sample of small Spanish firms. ${ }^{6}$ Our study takes a broader perspective. Our main focus, motivated by the analysis of Domar and Musgrave (1944), is not on variation in tax loss-offset rules but on variation in tax rates. Specifically, we focus on the sensitivity of risk taking to tax rates, on the way tax loss-offset provisions moderate this sensitivity, and on asymmetry in this sensitivity in the presence of constraints imposed by creditors on a firm's ability to increase risk.

Compared to the extant empirical literature on corporate risk taking, our main advantage is

\footnotetext{
${ }^{5}$ Among these other determinants are managerial risk aversion and career concerns (May 1995; Gormley and Matsa 2016), the sensitivity of CEO wealth to stock volatility (Coles, Daniel, and Naveen 2006), option compensation (Rajgopal and Shevlin 2002; Gormley, Matsa, and Milbourn 2013), inside debt (Cassell, Huang, Manuel Sanchez, and Stuart 2012; Choy, Lin, and Officer 2014), corporate governance (John, Litov, and Yeung 2008), SarbanesOxley (Bargeron, Lehn, and Zutter 2010), creditor rights (Acharya, Amihud, and Litov 2011), and diversification (Faccio, Marchica, and Mura 2011).

${ }^{6}$ Using a sharp regression discontinuity design, Langenmayr and Lester find that Spanish firms with revenues just above EUR 20 million significantly reduced their earnings volatility when their ability to offset losses was limited in 2011, as compared to firms just below the revenue threshold. One of our empirical findings is similar, in that U.S. firms reduce risk when state-level offset rules become less generous, though given the differences in research design, we view Langenmayr and Lester's results as having more limited external validity.
} 
identification: our diff-in-diff approach not only establishes a set of plausible counterfactuals taken from the same legal, regulatory, and business environment, but it also mitigates, when paired with a focus on adjacent states, omitted-variable biases resulting from the confounding influence of unobserved local shocks. These features of our research design go some way towards permitting a causal interpretation of our results, which is critical for academic research to be informative to policymakers (Leuz and Wysocki 2016).

Finally, our results add nuance to the hedging literature. A parallel literature on risk management shows that firms hedge to reduce income volatility with a view to increasing debt capacity (Smith and Stulz 1985; Graham and Rogers 2002). It is possible that increased hedging contributes to the tax-induced reduction in risk taking we observe. This would be interesting because the hedging literature has so far found little support for taxes being an important reason why firms engage in hedging.

\section{Research Design, Institutional Setting, and Sample and Data}

\subsection{Empirical Strategy}

We use a diff-in-diff framework to estimate the effect of changes in state corporate income tax rates on firms' risk-taking choices. Our baseline regression takes the following form:

$$
\Delta \operatorname{Risk}_{i, j, s, t}=\beta \Delta T_{s, t}^{+}+\gamma \Delta T_{s, t}^{-}+\theta \Delta Z_{s, t}+\delta \Delta X_{i, t-1}+\alpha_{j, t}+\varepsilon_{i, j, s, t}
$$

where $i, j, s$, and $t$ index firms, industries, states, and years, respectively. $\Delta$ is the first-difference operator. Risk $k_{i, j, s, t}$ is a measure of firm i's risk taking (defined in Section 2.3). $Z_{s, t}$ represents statelevel control variables measured as of year $t$, while $X_{i, t-1}$ is a vector of firm-level control variables measured as of $t-1 .^{7}$ The $\alpha_{j, t}$ are SIC4 industry-by-year fixed effects. $\varepsilon_{i, j, s, t}$ is the usual error term. Given the state-level nature of the tax variation we exploit, we cluster standard errors by state

\footnotetext{
${ }^{7}$ Consistent with prior research, we use beginning-of-year (i.e., year $t-1$ ) values for the firm-level controls as these variables are likely affected by a firm’s concurrent risk-taking choices (Gow, Larker, and Reiss 2016).
} 
(Petersen 2009). ${ }^{8}$

The variables of interest are $\Delta T_{s, t}^{+}$and $\Delta T_{s, t}^{-}$, which measure the magnitude of a tax increase or a tax cut in either a firm's home state or across its nexus states in year $t$. Details of these tax changes and how they are computed are provided in Section 2.2. Since each tax-change variable is measured in absolute terms, corporate risk taking is reduced in response to a tax increase if $\beta<0$ and increased in response to a tax cut if $\gamma>0$.

Estimating Eq. (1) in first-differenced form removes firm-specific fixed effects and potential confounding effects from time-invariant state-level conditions or policies (e.g., political parties or fiscal policies). An advantage of a first-differenced specification over a levels specification with firm fixed effects is that first-differencing can accommodate repeated treatments, treatment reversals, and asymmetry in firms' responses to tax changes. Including industry-by-year fixed effects removes unobserved time-varying industry shocks by comparing the behavior of treated and control firms in the same industry at the same point in time.

To illustrate our research design, consider Pennsylvania (PA). In 1991, PA raised its top corporate income tax rate from $8.5 \%$ to $12.25 \%$. Following this tax increase, stock market-listed firms headquartered in PA reduced risk by about $10 \%$ on average. From the point of view of an individual firm in PA, this tax shock is plausibly exogenous: presumably, no firm would have lobbied for the tax increase. Exogeneity with respect to individual firms' characteristics is not, however, sufficient to establish causality: other coincident developments, such as changes in investment opportunities in PA, could be responsible for the reduction in corporate risk taking.

To control for such contemporaneous developments, our baseline model in Eq. (1) compares risk changes among PA firms to the contemporaneous risk changes among firms in the same

\footnotetext{
${ }^{8}$ Our results are robust to alternative approaches (see the Online Appendix).
} 
industry that are located in other states without a tax change in 1991, say, in New York (NY). To the extent that PA firms and NY firms are faced with similar changes in their prospects, the contemporaneous change in risk among NY firms provides a counterfactual estimate of how PA firms’ risk choices would have evolved absent the tax increase. The difference-in-differences, that is, the difference across firms in different states of the within-firm risk change around the tax increase, provides an estimate of the tax sensitivity of corporate risk taking.

Eq. (1) generalizes this illustrative example in that it exploits variation in taxes across many states and years. For any change in corporate income taxes in state $s$ and year $t$, the potential control states are all those states that did not change their corporate income taxes in that year. In addition, Eq. (1) also controls for time-varying firm and state factors, as well as unobserved time-invariant firm characteristics and time-varying industry shocks.

As discussed in the introduction, a causal interpretation of the coefficients of interest in Eq. (1) requires that risk taking at treated and control firms follow parallel trends, that state tax changes do not coincide systematically with variation in local business cycles or other tax or non-tax state policies that might independently affect firms’ risk taking, and that changes in state tax policies be unanticipated. We present tests designed to address potential violations of these identifying assumptions in Section 3.2.

\subsection{Institutional Setting}

\subsubsection{Changes in state corporate income tax rates}

Table A.1 in the Online Appendix provides an overview of all changes in state corporate income tax rates over the period 1990 to 2011. We start in 1990 because one of our control variables requires two lags of cash flow statement data, and cash flow data are only available via Compustat since 1988. We end in 2011 to give firms time to adjust their risk profiles after taxes 
change. Panel A lists 40 tax increases in 24 states (including Washington, DC) affecting 1,152 sample firms in fiscal years 1990-2011, while Panel B lists 73 tax cuts in 27 states (including DC) affecting 4,920 firms in fiscal years $1990-2011 .^{9}$ The average tax shock increases tax rates by 93 basis points and the average tax cut reduces tax rates by 55 basis points.

Our main variables of interest are the magnitude of tax increase and magnitude of tax cut in a firm's headquarter state in a given fiscal year, in each case measured as the absolute value of the difference between this year's and last year's tax rate. From time to time, firms move their headquarters from one state to another. Compustat provides information only on a firm's current headquarter state. To remedy this flaw, we use Heider and Ljungqvist's (2015) hand-collected data on firms' historical headquarter states. Based on these data, the average (median) treated firm experiences a tax increase of 136 (106) basis points and a tax cut of 53 (44) basis points.

Firms are taxed in every state in which they have a physical presence (their so called "nexus" states) ${ }^{10}$ To reduce the scope for profit-shifting and tax arbitrage, states do not attempt to measure actual profits earned in-state. Instead, under the 1957 Uniform Division of Income for Tax Purposes Act, a multi-state firm's federal taxable income is apportioned to each nexus state using a formula based on an average of the fractions of the firm's total payroll, sales, and property located in that state. This has two consequences for our analysis. First, it is not necessary for us to map a firm’s projects to a specific state (which data limitations prevent us from doing): a firm can respond to a tax change in state A by changing the risk profile of its projects in any state it operates in. Second, the extent to which a multi-state firm is exposed to a

\footnotetext{
${ }^{9}$ In coding which firms are affected by tax changes when, we are careful to capture whether a tax change affects firms with fiscal years ending or beginning on or after the effective date. This affects when it makes sense for a firm to react. We lose 8 of Heider and Ljungqvist's (2015) 121 tax changes, partly because our sample starts later, partly because two of their tax changes (in North Dakota in 2007 and 2009) affect none of the firms satisfying our sampling criteria, and partly because we lack a clear prediction for how changes from gross receipts taxes to income taxes (or vice versa) affect firm risk-taking.

${ }^{10}$ As of 2011, three states (Nevada, South Dakota, and Wyoming) do not impose income taxes, and three states (Ohio, Texas, and Washington) impose gross receipts taxes rather than income taxes.
} 
given state income tax change depends on the extent of its nexus to that state.

To measure the magnitude of tax shocks experienced by multi-state firms more accurately, we approximate the geographic distribution of their tax liabilities using location data for their subsidiaries, branches, and plants. Specifically, we match Compustat firms by name to the National Establishment Time Series (NETS) database, which contains a comprehensive record of all business establishments in the U.S. since $1989 .{ }^{11}$ We then calculate the weighted change in state tax rates in a firm's nexus states in a fiscal year as follows:

$$
\Delta \text { tax rate }_{i, t}=\sum_{s}\left(\frac{1}{2} \frac{\text { employees }_{i, s, t}}{\text { employees }_{i, t \text { total }, t}}+\frac{1}{2} \frac{\text { sales }_{i, s, t}}{\text { sales }_{i, \text { total }, t}}\right) \Delta T_{s, t},
$$

where employees $s_{i, s, t}$ and sales $s_{i, s, t}$ are firm i's number of employees and sales in state $s$ in year $t$, respectively, and employees $i_{i, t o t a l, t}$ and sales $s_{i, t o t a l, t}$ are the corresponding firm totals across all nexus states in year $t$, respectively. $\Delta T_{s, t}$ is the change in the corporate income tax rate in state $s$ in year $t$. Eq. (2) approximates a firm's nexus with each state using a 50/50 average of the fractions of the firm's total employment and sales in that state. Based on the magnitude and sign of the weighted tax change in Eq. (2), we define two alternative variables of interest: nexus-weighted tax increase and nexus-weighted tax cut, in each case measured in absolute terms.

\subsubsection{Tax loss carryback/carryforward rules}

The effect of taxes on risk taking is moderated by tax loss-offset provisions (Domar and Musgrave 1944). Most states have loss-offset rules. For example, in 2011, about a third of states allow firms to offset current losses against income earned in the past 2 or 3 years, and all states allow firms to carry current losses forward, for periods ranging from 5 to 20 years. To examine heterogeneous treatment effects, we collect data on state tax loss carryback/carryforward rules over our sample period. We also use changes in these rules as an alternative source of policy

\footnotetext{
${ }^{11}$ Neumark, Zhang, and Wall (2007) assess NETS along various dimensions and conclude that it is generally reliable. The name match is borrowed from Farre-Mensa and Ljungqvist (2016).
} 
shocks to examine the effects of corporate taxation on firm risk taking.

Table A.2 in the Online Appendix provides details of changes in state tax loss carryback/carryforward rules for our sample period. Panel A lists 15 increases in the loss carryback period in 11 states (including DC) affecting 430 sample firms in fiscal years 19902011, while Panel B lists 36 reductions in the loss carryback period in 26 states (including DC) affecting 1,164 firms. At the state-level, the average increase is 2.13 years while the average reduction is 1.75 years. The average (median) treated firm experiences an increase of 2.04 (2) years and a reduction of 1.83 (1) years.

Panel C lists 47 increases in the loss carryforward period in 37 states (including DC) affecting 5,349 sample firms in fiscal years 1990-2011, while Panel D lists 10 reductions in the loss carryforward period in eight states affecting 1,828 firms. The variation in carryforward periods is larger than for carryback periods. At the state-level, increases average 6.43 years, while reductions average 8.2 years. The average (median) treated firm experiences an increase in the carryforward period of 6.65 (5) years and a reduction of 9.58 (10) years.

\subsubsection{Other state-level tax policy changes}

Appendix A shows that changes in state corporate income tax rates and loss-offset rules rarely coincide with each other or with changes in investment incentive programs (i.e., tax credits for investment, R\&D, and job creation). It is thus unlikely that our results are confounded by coincident changes in these state policies. The only area of overlap we find is with bank taxes: 28 of the 40 corporate tax increases coincide with bank tax increases and 56 of the 73 corporate tax cuts coincide with bank tax cuts. Since bank tax changes could trigger changes in the supply of bank loans, we verify that our results are robust to controlling for changes in bank taxes. ${ }^{12}$

\footnotetext{
${ }^{12}$ Banks have a unique status for state tax purposes (Koch 2005). They are taxed on a different schedule from corporations and so are subject to their own tax changes. When a state increases its bank tax, it reduces the after-tax
} 


\subsection{Sample and Data}

\subsubsection{Sample}

Our sample begins with all firm-year observations in the merged CRSP-Compustat database for fiscal years 1990 to 2011. We exclude financial firms (SIC=6; 27,197 observations), utilities (SIC=49; 7,174 observations), public-sector entities (SIC=9; 2,187 observations), non-U.S. firms (17,289 observations), and firms headquartered outside the U.S. (954 observations). We delete firms without stock return data, firms not traded on a major U.S. stock exchange (NYSE, Amex, or Nasdaq), and firms with a CRSP share code $>11$ (47,666 observations). Observations with negative or missing total assets (30,281 observations) are also excluded. Requiring non-missing data for our risk measures and control variables and their lagged values leaves us with a final panel of 64,447 firm-year observations for 8,046 firms.

\subsubsection{Measures of risk taking}

We view a firm as a portfolio of projects which can differ in their risks. At each instant, the firm can close down existing projects and add new ones. While we do not observe these projectlevel choices, we do observe the aggregate cash flows they generate. We thus measure corporate risk taking as the firm-level volatility of aggregate cash flows, defined in two different ways.

Our first measure of risk taking, ROA volatility, is the standard deviation of seasonally adjusted quarterly pre-tax returns on assets $(R O A)$ over the three-year period from year $t$ to $t+2$, where pre-tax ROA is operating income after depreciation (i.e., earnings before interest and taxes) divided by the book value of total assets and the seasonal adjustment for firm $i$ in quarter $q$ of year $t$ is computed as $\Delta R O A_{i, t, q}=R O A_{i, t, q}-R O A_{i, t-1, q}$ (Correia, Kang, and Richardson 2015). The first difference of ROA volatility for year $t$ is the log-transformed standard deviation computed 
over years $t$ to $t+2$ minus the log-transformed standard deviation computed over years $t-3$ to $t-$ $1 .^{13}$

Our second measure of risk taking, ROIC volatility, is the standard deviation of seasonally adjusted quarterly pre-tax returns on invested capital (ROIC) over a three-year period from year $t$ to $t+2$. Following Lundholm and Sloan (2012), we compute ROIC as operating income after depreciation divided by the sum of debt, minority interests, preferred stock, and common stock. ${ }^{14}$

Note that because both variables are measured before interest and taxes, they capture business (or asset) risk rather than the effects of financing risk. This is important because it is well-known that tax changes can prompt firms to change their financial leverage. Our measures are thus designed to isolate the effects of taxes on the real (rather than financial) risks firms take.

In a robustness test, we use two market-based measures as alternative measures of risk taking, namely, the standard deviation of stock returns and the de-leveraged standard deviation of stock returns. We prefer the earnings-based risk measures because they more likely reflect a firm's choice of risk (stock returns not being under the firm's control).

\subsubsection{Control variables and descriptive statistics}

Following prior research (e.g., Coles, Daniel, and Naveen 2006), our baseline specification in Eq. (1) controls for the following firm characteristics: age, size, market-to-book ratio, book leverage, cash surplus, loss carry-forward, sales growth, and annual stock return. (See Appendix B for definitions.) Table 1 presents summary statistics. The average (median) ROA volatility is $6.8 \%$ (3.8\%), and the average (median) ROIC volatility is $10.6 \%$ (5.3\%). Given the skewed distribution of these two risk measures, we use their log-transformed values in our regression

\footnotetext{
${ }^{13}$ To construct these measures, we use data from Compustat Quarterly for fiscal years 1987 to 2013.

${ }^{14} R O I C$ is also called return on net operating assets $(R N O A)$. Some researchers view non-operating cash as negative debt and subtract total cash from invested capital in computing ROIC. However, in the presence of financial frictions, non-operating cash should not be viewed as negative debt (Acharya, Almeida, and Campello 2007). Moreover, firms generally do not disclose how much cash they hold for non-operating purposes (Lundholm and Sloan 2012).
} 
analysis. The average firm in our sample is 19.6 years old and has total assets of $\$ 1,755.2$ million.

Our baseline specification also controls for two state-level variables intended to capture local variation in economic conditions: the real growth rate in gross state product (GSP) and the state unemployment rate. The mean home-state GSP growth rate is $2.7 \%$ and the mean unemployment rate is $5.9 \%$. We consider further state-level controls when we address identification concerns.

\section{State Corporate Income Taxes}

\subsection{Baseline Estimates of the Effect of State Corporate Income Tax Changes on Risk Taking}

Table 2 reports the results of estimating Eq. (1). Columns 1 and 2 model how firms respond to tax changes in their headquarter states. In the regression with $R O A$ volatility as the dependent variable (column 1), the coefficient on magnitude of tax increase is -0.019 ( $p=0.007)$, suggesting that firms reduce risk taking in response to a tax increase. The effect is both statistically and economically significant. The point estimate suggests that the average treated firm, whose homestate tax rate increases by 136 basis points, reduces its risk taking by $2.6 \%$ relative to other firms in the same industry that are not subject to tax changes in their own home state that year. In column 2, where we use ROIC volatility as the dependent variable, the coefficient on magnitude of tax increase is $-0.020(p=0.006)$ - nearly identical to the point estimate in column 1.

The models shown in columns 1 and 2 relate the difference in volatility measured over fiscal years $t$ to $t+2$ and volatility measured over fiscal years $t-3$ to $t-1$ to tax changes occurring in fiscal year $t$. In columns 3 and 4 , we lag the tax changes by one year to allow for delays in firms' responses to tax changes. This produces stronger results for ROA volatility and similar results for ROIC volatility: ROA volatility falls by 2.6 percentage points for every one-percentage-point increase in the tax rate $(p<0.001)$, while ROIC volatility falls by 1.9 percentage points ( $p=0.047$ ).

Columns 5 and 6 of Table 2 model how firms respond to contemporaneous changes in their 
nexus-state weighted income tax rates. As discussed earlier, the weighted tax-change measures attempt to approximate the shock to a firm's actual state-tax burden. In column 5, where the dependent variable is ROA volatility, the coefficient on nexus-weighted tax increase is -0.024 $(p=0.011)$, suggesting that a one-percentage-point increase in a firm's nexus-weighted tax rate reduces its risk taking by $2.4 \%$ relative to control firms in the same industry and year. In column 6, the coefficient on nexus-weighted tax increase is $-0.032(p=0.005)$ when we use ROIC volatility as the dependent variable. The effects estimated for nexus-weighted tax changes are thus larger than those for home-state tax changes, confirming our prediction that ignoring the geographic distribution of firms' tax bases understates the tax sensitivity of firms' risk taking. Results using home-state tax changes are hence conservative. ${ }^{15}$

The contemporaneous effect of tax cuts is to increase risk taking. The effect is large, but unlike the effect of tax increases, it is not statistically significant. For example, in column 1, the coefficient on magnitude of tax cut is 0.016 with a $p$-value of 0.322 . The results for ROIC volatility or when using nexus-weighted tax changes show a similar pattern. When lagged, the effect of tax cuts on risk taking is close to zero. ${ }^{16}$

The finding that firms more strongly and more consistently respond to tax increases than to tax cuts could be a power problem, ${ }^{17}$ or it could be due to external constraints on firms' ability to increase risk. A natural source of constraints on corporate risk taking is creditors, whose claims fall in value as risk increases. To investigate this possibility, we sort firms into those with low

\footnotetext{
${ }^{15}$ Among the control variables, we find that risk increases by less as the firm ages or grows in size. Firms with a higher market-to-book ratio change risk more, while firms with higher financial leverage, more cash surplus, and higher stock returns change risk less. Firms with higher sales growth rates and loss carryforwards change risk more. The two state-level control variables are also marginally significant. Firms increase risk as the GSP growth rate falls and as the state unemployment rate increases.

${ }^{16}$ While the difference in the sensitivity to tax increases and to tax cuts is small and not statistically significant for contemporaneous tax changes, it is economically large and statistically significant for ROA volatility when we use lagged tax changes.

${ }^{17}$ This reduced sensitivity to tax cuts is not due to tax cuts being smaller, on average, than tax increases in our sample: as Table A.4 in the Online Appendix shows, similar results obtain when we focus on large tax cuts.
} 
financial leverage (assumed to face fewer constraints) and those with high leverage (assumed to face more constraints), measured as of the end of previous fiscal year. Table 3 reports the results. Consistent with our conjecture, firms with low leverage do, in fact, increase risk taking significantly in response to a tax cut, whereas firms with high leverage do not. ${ }^{18}$

A more direct way to test our conjecture would be to measure the tightness of contractual constraints imposed on borrowers in the form of covenants. While data on covenants are available only for a subset of our sample firms, and even then are patchy, we find quite similar results: firms with few or lax covenants increase risk more strongly in response to tax cuts than do firms with many or tight covenants; see Table A.5 in the Online Appendix.

\subsection{Identification Challenges}

Threats to a causal interpretation of the findings reported in the previous section come from potential violations of our identifying assumptions. In this section, we report dynamic tests to shed light on the parallel-trends assumption, tests designed to deal with changes in local economic conditions that coincide with state tax changes, and tests that deal with potential anticipation effects. If anything, these refinements strengthen our conclusion insofar as they yield typically somewhat larger point estimates of the sensitivity of corporate risk taking to tax increases. We also continue to find evidence that firms respond to tax changes asymmetrically.

\subsubsection{Parallel trends}

As in any diff-in-diff test, a causal interpretation of the effect of tax changes on risk taking requires that treated and control firms follow parallel trends absent the tax change. To test for parallel trends, Table 4 includes lead terms of the tax change variables. These are measured as of

\footnotetext{
${ }^{18}$ Table 3 also shows that firms' sensitivity to tax increases does not vary with their leverage. This rules out an alternative interpretation of our baseline results, namely that firms reduce risk when taxes increase not because their tax function has become more convex but simply because doing so allows them to more easily increase their financial leverage.
} 
year $t+3$, given that we use 12 quarters of earnings data to construct our volatility measures. The point estimates for the lead terms are economically tiny and not statistically different from zero, suggesting that risk follows parallel trends at treated firms and controls before state income tax rate changes. One implication of these findings is that firms do not anticipate future changes in state income taxes (or if they do, that they wait to change risk until the tax changes affect shareholder wealth). This, in turn, lessens concerns regarding potential anticipation effects.

Table 4 also allows for potential delays in firms' responses to tax cuts and post-shock reversals in the effect of tax increases by including three-year lags. The coefficient for lagged tax increases is negative, indicating that firms do not subsequently reverse the reduction in risk following a tax increase. Given the relatively large point estimate, the effect of a tax increase appears not only persistent but also increasing over time. In column 1, the cumulative effect is $0.035(p<0.001)$, suggesting that a one-percentage-point increase in the state corporate income tax rate in year $t$ reduces $R O A$ volatility by $3.5 \%$ over the next six years (i.e., $R O A$ volatility measured over years $t$ to $t+2$ and over years $t+3$ to $t+5$ ). Given an average tax increase of 136 basis points, the average treated firm thus reduces its risk by a cumulative $4.8 \%$. For tax cuts, the coefficient on the lag term is economically small and statistically insignificant.

\subsubsection{Local business cycle effects and other state-level confounds}

What might be called "local shocks" are a standard challenge to research designs that exploit local policy changes. A priori, there is little reason to expect tax changes to be "exogenous" rather than to occur in response to local shocks. The identification concern then is that changes in local economic conditions coincide with, or even drive, state changes in tax rates, and that it is these changes in local economic conditions - rather than the tax changes - that cause firms to change their risk taking. 
We next present tests designed to deal with local shocks of three different types: (a) observed or unobserved changes in local economic conditions that coincide with state tax changes and whose effects diffuse across state borders, and either (b) observed or (c) unobserved changes in economic policies that coincide with state tax changes and whose effects stop at the state border.

To address local shocks of type (a), we perform a neighboring-state test, ${ }^{19}$ by dropping faraway control states, restricting the set of control firms to those located in states bordering the treated state, and including neighboring-state-by-year fixed effects to difference away unobserved variation in local economic conditions. ${ }^{20}$ The essence of a neighboring-state test is to exploit a policy discontinuity along a geographic boundary under the maintained assumption that there exists an unobserved time-varying confound which might bias the treatment effect of interest. The aim is to difference away the confound in order to obtain an unbiased estimate of the treatment effect. In our setting, the policy in question is a tax change $\Delta T_{A}$ in state A which applies only in state A but not in neighboring state B (this is the policy discontinuity). The outcome variable is the change in risk, $\Delta R$. The potential time-varying confound (denoted by $\Delta Y$ ) could, for example, be business cycle variation.

The identifying assumption is that $\Delta Y_{A} \approx \Delta Y_{B}$ (both states are exposed to roughly the same business cycle variation). Under this identifying assumption, $\left(\Delta R_{A} \mid \Delta T_{A}, \Delta Y_{A}\right)-\left(\Delta R_{B} \mid \Delta Y_{B}\right)$ is a consistent estimate of the effect of taxes on risk taking, given that $\Delta Y_{A}-\Delta Y_{B} \approx 0$, and so the unobserved confound can be differenced away using a fixed effect common to states A and B in the tax-shock year. Economically speaking, cross-border neighbors establish the counterfactual risk-taking response to the local business cycle variation of firms not affected by a tax increase,

\footnotetext{
${ }^{19}$ See Holmes (1998), Huang (2008), Dell (2010), and Dube, Lester, and Reich (2010).

${ }^{20}$ Note that, in so doing, we drop observations for states that are treated in another year but are not the neighbor of a treated state in the current year.
} 
and this counterfactual response is then subtracted from the treated firms' response to the treatment. In other words, comparing treated firms to their immediate neighbors helps ensure that trends are parallel after removing the effects (if any) of common variation in local conditions. ${ }^{21}$

Columns 1 and 2 of Table 5 report the results. Compared to firms in neighboring states, treated firms reduce both ROA volatility and ROIC volatility by $2.5 \%$ ( $p=0.016$ in column 1 and $p=0.037$ in column 2) in response to a one-percentage-point increase in the corporate tax rate. Thus, controlling for unobserved local shocks increases the point estimates a little compared to the Table 2 baseline. Tax cuts continue to have no effect on risk taking. Overall, these patterns confirm that our findings are not driven by unobserved variation that coincides with the tax changes but diffuses across state borders.

A related threat to identification is that there could be an interaction between time-varying local conditions and a state's time-invariant policies. Say states A and B are exposed to the same business cycle variation but state A is a business-friendly state while state B believes in heavy regulation. Then firms in state A will be more sensitive to the common business cycle variation than firms in state B. This, in turn, would violate a version of the identifying assumption, namely that absent the tax change in state $\mathrm{A}, \Delta R_{A}\left|\Delta Y_{A} \approx \Delta R_{B}\right| \Delta Y_{B}$. In this scenario, our test would wrongly attribute the difference in risk taking, $\left(\Delta R_{A} \mid \Delta T_{A}, \Delta Y_{A}\right)-\left(\Delta R_{B} \mid \Delta Y_{B}\right)$, to the tax change rather than to the moderating effect on $\Delta Y_{B}$ of state B's heavy regulatory burden.

For such an interaction between time-varying local conditions and time-invariant policies to spuriously produce our results, it would have to be the case that firms' risk choices were systematically more sensitive to changes in economic conditions in tax-increasing states than in neighboring control states. We view this as unlikely for two reasons. First, while it is conceivable

\footnotetext{
${ }^{21}$ The neighboring-state test does not assume that neighboring states have the same or similar policies. Assume there is variation in policies across neighboring states. If these policies do not themselves change at the time of the tax change, they are differenced away by our first-difference research design and so cannot confound the results.
} 
that a particular constellation of policy differences across neighboring states and local conditions could produce this identification challenge in some place at some point in our data, it is much less likely to systematically confound our results, given that we exploit not one but 113 tax changes that are neither clustered in time nor in space. Second, the large number of tax changes means that every state (bar Montana) that is treated at some time also acts as a control state at some other time in our panel. The effects of cross-state differences in the sensitivity of risk taking to local conditions thus cancel out. ${ }^{22,23}$

This leaves confounds whose variation coincides with the tax changes and whose influence stops at the state border. Some of these are observable, others unobservable. Prominent potential confounds of the observable variety include the state-level policy changes listed in Appendix A. Columns 3 and 4 of Table 5 control for changes in state taxes on bank profits and in investment incentive programs (i.e., tax credits for investment, $R \& D$, and job creation), some of which coincide with corporate tax changes. Doing so increases the estimated effect of tax increases by around a third (from -0.025 to around -0.033 ). The effect of tax cuts remains statistically insignificant, and the difference between the sensitivities to tax cuts and tax increases is economically large and statistically significant ( $p=0.007$ in column 3 and $p=0.021$ in column 4 ).

Altonji, Elder, and Taber (2005) propose dealing with confounds of the unobservable variety by estimating the degree of selection on observables and using it as a guide to the degree of selection on unobservables. In our context, this entails gauging the potentially confounding role of state-level political and economic conditions that may affect state tax policy. As a first step,

\footnotetext{
${ }^{22}$ If risk-taking in business-friendly state $\mathrm{A}$ always responds to the business cycle while risk-taking in state $\mathrm{B}$ does not, then the treatment effect is $(A-B)$ when $A$ is treated and $(B-A)$ when $B$ is treated, so that the overall treatment effect averages zero (i.e., $(\mathrm{A}-\mathrm{B})+(\mathrm{B}-\mathrm{A})=0$ ). Our results reject this null hypothesis, at least for tax increases.

${ }^{23}$ A related concern is that tax changes in one state may trigger changes in the behavior of firms in a neighboring state. To investigate such cross-border spillovers, we conduct a test in the spirit of Table 5 that restricts the set of control firms to those located in states not neighboring the treated state. As Table A.6 in the Online Appendix shows, our inferences are unchanged.
} 
columns 5 and 6 of Table 5 include the main determinants of state tax changes as identified by Heider and Ljungqvist (2015). This increases the estimated sensitivity to tax increases further, to $3.6 \%(p=0.012)$ for $R O A$ volatility and $4.1 \%(p=0.006)$ for ROIC volatility. The effect of tax cuts on risk taking continues to be economically small and statistically insignificant.

In the next step, we follow Christensen et al. (2016) who propose a falsification test of the potential bias induced by selection on unobservables. The test regresses the part of the outcome variable that is related to observed determinants of the suspected confounds (here: the change in risk taking predicted from our economic and political controls) on the treatment variable (here: the change in the tax rate). A small coefficient in the falsification test, compared to the estimated treatment effect in the baseline test, suggests that the baseline treatment effect is unlikely to reflect unobserved confounds. As Table A.7 in the Online Appendix shows, the point estimates in the falsification test are tiny and statistically insignificant. These results reinforce our conclusion that unobserved variation in local conditions is unlikely to be severe in our setting.

\subsubsection{Anticipation effects}

If firms plan their current policies based on the tax rates they expect to face in the future, their observed responses to an actual tax change may not uncover the causal effect of taxes on their behavior. To see why, consider a tax increase that turns out smaller than expected. This may cause corporate policy to change in a way normally expected after a tax cut (since the tax rate increased by less than expected), which in turn would confound the interpretation of the observed treatment effect (as the econometrician does not observe the firm's expectations). Having said that, the absence of significant lead effects in Table 4, discussed earlier, suggests that firms do not change risk in anticipation of future tax changes.

As Hennessy and Strebulaev (2015) note, anticipation effects only undermine identification if 
the corporate policy in question is subject to adjustment costs, so that the firm must plan ahead in order to reach its desired position over time given its expectations. The next subsection explores empirically various mechanisms by which firms may change risk taking in response to tax changes. Some of these are more plausibly subject to adjustment costs than others. The one that we find to be strongest in the data is a short-term mechanism with few obvious adjustment costs.

There is one (somewhat obvious) scenario, besides the absence of adjustment costs, for when anticipation effects do not pose an identification challenge: if policy changes are unanticipated. More formally, a necessary and sufficient condition for correct inference about causal effects is that the policy variable is a Martingale (Hennessy and Strebulaev 2015), which in our context means that state tax rates follow a random walk. Using three unit root tests, Ljungqvist and Smolyansky (2016) largely fail to reject the null hypothesis of a random walk. ${ }^{24}$

Specifically, in separate augmented Dickey-Fuller tests on each state's time series of tax rates from 1969 to 2013, Ljungqvist and Smolyansky (2016) fail to reject the presence of a unit root in each state and DC, suggesting corporate tax rates follow a random walk in every state. Realizing that some states condition their tax policy on the tax policies of their neighbors (Heider and Ljungqvist 2015), Ljungqvist and Smolyansky also test the null hypothesis that each state in a given regional “cluster” has a unit root while allowing for cross-sectional dependence in tax rates across states. Clusters are defined either as a state and its contiguous neighbors (giving 49 clusters, including DC’s but excluding Alaska and Hawaii) or as states that are located in a given Census region. The null cannot be rejected at standard significance levels except in Connecticut and in Massachusetts and their respective contiguous neighbors. Within Census regions, the null is never rejected at the 5\% level; it is rejected at the $10 \%$ level in New England.

To see whether anticipation effects in states whose tax rates do not follow a random walk

\footnotetext{
24 These findings echo Barro (1990), who reports that federal taxes follow a random walk.
} 
may confound our results, Table 6 excludes firms headquartered in Connecticut or Massachusetts (columns 1 and 2 ) or in New England as a whole (columns 3 and 4). Doing so marginally reduces the magnitude of the treatment effect of tax increases, to between -0.014 and -0.018 $(p<0.05)$. Tax cuts continue to have no significant effect on the average firm's choice of risk.

An alternative to this econometric way of classifying tax changes as potentially anticipated is the "narrative approach" of Romer and Romer (2010). Heider and Ljungqvist (2015) examine the political economy events surrounding all state tax changes affecting at least 100 firms since 1989 to identify potentially anticipated tax changes. Based on their findings, columns 5 and 6 of Table 6 exclude firms headquartered in Colorado, Connecticut, Minnesota, or New York (all of which experienced sequences of tax cuts). This yields sensitivities to tax increases of between -0.016 and -0.019 $(p<0.05)$, again marginally smaller than those reported in our baseline tests.

Collectively, the results in Table 6 suggest that anticipation effects do not play a major role in contaminating our findings. This, in turn, increases our confidence in the external validity of our findings: to the extent that state tax rates truly follow a random walk, the patterns we document should apply more broadly than just in the setting and time period we study.

\subsection{Mechanisms}

By what means do firms reduce risk in response to state corporate income tax increases? The reasonably fast reduction in earnings volatility (measured over the three-year period from $t$ to $t+2$ ) suggests that firms change the risk profile of their existing operations. One way to do so is to make changes to the operating cycle: the process by which cash is transformed into raw materials, work in progress, finished goods, accounts receivable, and eventually back into cash. Shortening the operating cycle (for example, by reducing the amount of cash tied up in inventory that could go unsold) puts less capital at risk and so reduces earnings volatility. Essentially, the firm can 
reduce its operating risk by reducing its investment in working capital, and it can do so relatively quickly and, potentially, without incurring substantial adjustments.

Panel A of Table 7 provides evidence of such reductions in operating risk. In the year following a tax increase, we see firms reducing their operating cycles by an average of 1.7 days and 3.05 days for every one percentage-point increase in their home-state or nexus-weighted tax rate, respectively. (Tax cuts have no effect on operating cycles.) Relative to the sample average operating cycle of 83.6 days, this implies a reduction of $2 \%$ to $3.6 \%$ for the average treated firm. About half of this reduction comes from a reduction in inventory holding periods, which fall by an average of 0.72 to 1.47 days in columns 2 and $5 .^{25}$

Another way firms could reduce operating risk is by reducing operating leverage, that is, the sensitivity of profits to changes in output. In practice, reducing operating leverage requires turning fixed costs into variable costs. Whether the tax shocks are on average large enough to justify the expense involved in making costs more flexible is an open question. For example, making labor costs more flexible may involve protracted negotiations with unions and increase the risk of strikes (a form of adjustment cost). As columns 3 and 6 of Panel A show, we fail to find evidence of firms changing their operating leverage in response to state tax changes. ${ }^{26,27}$

Given the further reduction in risk taking observed over the medium term (i.e., the three-year period $t+3$ to $t+5$ in Table 4), firms may also change the risk profiles of their investment projects. Panel B of Table 7 begins by showing that firms do not adjust the level of their capital

\footnotetext{
${ }^{25}$ Though not shown to conserve space, the two other components of the operating cycle, the average number of days to collect receivables and pay payables, do not change significantly.

${ }^{26}$ Another way firms can fine-tune their risk profiles in response to state tax rate changes is hedging (Graham and Smith 1999; Graham and Rogers 2002). Data on hedging activities are not systematically available.

${ }^{27}$ Table A.8 in the Online Appendix reports two robustness tests. The first restricts the set of control firms to those located in neighboring states, following Table 5 . This reduces the effect of tax increases on changes in operating cycles somewhat, though the effect remains both economically and statistically significant. The second shows that firms do not change their operating risk in response to a tax cut, regardless of their financial leverage (coded as in Table 3), possibly because doing so would reduce operational efficiency.
} 
expenditures or $R \& D$ spending in response to state tax changes: the tax sensitivity of either is both economically and statistically zero, consistent with Asker, Farre-Mensa, and Ljungqvist (2015). ${ }^{28}$ This finding leaves open the possibility that firms instead respond to tax increases by changing project risk. For example, firms may choose safer R\&D projects (say, to enhance the quality or variety of their existing products) over riskier ones (say, to invent new products).

Project risk is not directly observable, but its effect on cash flows is potentially measurable. To see how, start from the observation that R\&D has an asymmetric effect on sales: all else equal, successful R\&D projects boost the firm's sales while failed R\&D projects have no (immediate) effect. This insight gets around the problem that accounting data reveal only R\&D inputs (i.e., spending), not R\&D outputs (i.e., new products or processes that generate sales): an increase in the sensitivity of sales to $R \& D$ spend implies an increase in $R \& D$ outputs for a given amount of R\&D spend. Next, consider a mean-preserving increase in R\&D risk. This would increase the sensitivity of sales to R\&D spend if the project succeeds and leave it unchanged if the project fails. On average, therefore, an increase in R\&D risk results in an increase in the sensitivity of sales to $R \& D$ spend. The opposite holds for a reduction in $R \& D$ risk.

Using a measure called the Research Quotient ${ }^{\mathrm{TM}}$ (available on WRDS), Panel B shows that the sensitivity of sales to R\&D spend falls after a tax increase, consistent with firms reducing R\&D risk. The effect is not immediate - it takes on average between one and three years for a tax increase to reduce the R\&D sensitivity of sales - and not overly strong statistically.

A cautious interpretation of the findings in Table 7 is that the most prominent mechanism by which firms reduce risk in response to state corporate income tax increases involves making changes to the operating cycle. Since such changes should be relatively easy to reverse, they

\footnotetext{
${ }^{28}$ As Table A.9 in the Online Appendix shows, we similarly find no evidence that firms change their M\&A activities or reduce risk by engaging in diversifying acquisitions.
} 
should not involve substantial adjustment costs, reducing concerns about anticipation effects that are not already allayed by Ljungqvist and Smolyansky’s (2016) finding that state tax rates mostly follow a random walk or by the auxiliary evidence reported in our previous subsection.

\subsection{Robustness Tests}

Before turning our attention to the moderating effect of tax loss-offset rules, we briefly consider two robustness tests.

Our baseline tests use ROA volatility and ROIC volatility to measure firm risk. Prior research on corporate risk taking often uses stock return volatility to measure a firm’s choice of risk. Table A.10 in the Online Appendix shows that our findings are robust to using equity volatility instead of earnings volatility: a firm's annual stock return volatility falls by around $2 \%$ following a tax increase and is invariant to tax cuts, and the difference between the two tax sensitivities is economically large and statistically significant.

Our results may be driven by tax-related changes in earnings management. ${ }^{29}$ To investigate this concern, we test if a firm's performance-matched discretionary accruals (Kothari, Leone, and Wasley 2005) vary with tax changes, but find no evidence that they do (see Table A.11 in the Online Appendix). This is consistent with Graham's (2006) observation that “tax incentives appear to be a second-order consideration, rather than a dominant influence on earnings management” (p. 663). In addition, equity-based measures of risk taking, such as those modeled in Table A.10, are not affected by earnings management, further alleviating this concern.

\section{State Tax Loss-Offset Rules}

\subsection{Heterogeneous Treatment Effects}

According to Domar and Musgrave's (1944) theory, the effect of personal income taxes on

\footnotetext{
${ }^{29}$ Scholes, Wilson, and Wolfson (1992) find that firms respond to anticipated reductions in federal tax rates by delaying recognizing income. Maydew (1997) provides evidence that firms shift income to benefit from loss-offsets.
} 
individual risk taking is negative in the absence of loss-offsets. The same is true in the corporate arena. However, if firms can offset losses against past or future profits, the effect of taxes on risk taking becomes more complex. On the one hand, income taxes discourage risk taking by reducing the per-unit benefit of risk taking. On the other hand, loss-offset rules essentially make the government shoulder part of the losses. Thus, both the benefit of risk taking and the level of after-tax cash flow risk are reduced. If complete offset of losses is possible, variation in tax rates may have no net effect on risk taking.

To test this prediction, we partition the sample based on the carryback and carryforward rules in effect in each firm's home state in a given fiscal year. Specifically, we code firms as having a low ability to offset losses when their home state allows no loss carrybacks and no more than 10 years of loss carryforwards. Otherwise, we code firms as having a high ability to offset losses. ${ }^{30}$

Table 8 presents the results of estimating Eq. (1) in the partitioned samples. For firms with a low loss-offset ability, the sensitivity of ROA volatility and ROIC volatility to a tax increase is 0.026 ( $p=0.010$ in column 1$)$ and -0.033 ( $p=0.008$ in column 3$)$, respectively. For firms with a high loss-offset ability, the sensitivity is -0.010 ( $p=0.391$ in column 2$)$ and -0.004 ( $p=0.817$ in column 4), respectively. ${ }^{31}$ These results suggest that the negative effect of tax increases on risk taking is largely driven by firms located in states with weak loss-offset provisions, consistent with the prediction that the effect of corporate income taxes on risk taking is attenuated by the ability to offset tax losses against past or future profits.

\subsection{State Loss-offset Rules and Risk Taking}

Our baseline tests investigate firms' responses to tax rate changes while our tests of heterogeneous treatment effects examine if firms' responses to tax rate changes are moderated by

\footnotetext{
${ }^{30}$ These cutoffs are arbitrary but, as Table A.12 in the Online Appendix shows, not selective.

31 The difference between the coefficients on magnitude of tax increase in the two subsamples, although economically large, is only statistically significant when we use ROIC volatility as the dependent variable.
} 
tax loss-offset rules. We next test if changes in loss-offset rules affect risk taking independently. A reduction in the number of years that losses can be carried back or forward essentially reduces the extent to which the government shares in a firm's risks, analogous to a tax rate increase. Thus, we expect that reductions in the generosity of carryback or carryforward rules lead to lower risk taking. The opposite argument can be made for an increase in the length of carryback or carryforward periods (subject to creditors constraining firms' ability to increase risk).

Table 9 examines loss-offset rule changes both in a firm's home state (in Panel A) and across its nexus states (in Panel B). ${ }^{32}$ We allow for asymmetric responses by separately including increases and reductions in the length of loss carryback or carryforward periods. For both homestate and nexus-weighted changes, and whether we model risk as ROA volatility or ROIC volatility, we find an asymmetric response to changes in carryback rules: firms reduce risk taking as carryback rules are made less generous but do not respond when the rules become more generous. ${ }^{33}$ Since a shorter carryback period amounts to a tax increase, these patterns are consistent with our baseline finding that firms reduce risk taking in response to an increased tax burden but do not significantly increase risk taking in response to a reduced tax burden.

The response to changes in carryforward rules is different: firms respond to more generous carryforward rules by increasing risk (sometimes significantly so). However, these effects are economically small. Firms do not respond when carryforward rules become less generous.

The contrast between firms’ risk-reducing response to less generous carryback rules and their indifference to less generous carryforward rules is consistent with claims in the literature that

\footnotetext{
${ }^{32}$ For the latter, we estimate nexus-weighted changes in the length of tax loss carryback/carryforward periods using Eq. (2) (i.e., the formula used to estimate nexus-weighted changes in tax rates), after replacing tax rate changes with changes in the length of loss carryback/carryforward periods.

${ }^{33}$ The results are stronger for nexus-weighted changes than for home-state changes. They are robust to controlling for the tax rate changes from our baseline tests (see columns 3 and 4). This is not surprising: as Appendix A shows, changes in state corporate income tax rates rarely coincide with changes in state tax loss-offset rules.
} 
carrybacks allow firms to claim cash taxes back immediately when incurring losses whereas the benefit of carryforwards is more uncertain (Langenmayr and Lester 2015).

Overall, using changes in state tax loss-offset rules yields results that reinforce our conclusion from using tax-rate changes that increasing a firm’s tax burden reduces its willingness to take risk.

\section{Conclusions}

We ask whether and how corporate income taxes affect firms’ risk taking. Based on theories of the effect of personal income taxes on individual risk taking, we predict a negative effect of corporate taxes on corporate risk taking. Using staggered changes in corporate tax rates across U.S. states, we provide evidence that firms reduce risk when tax rates increase, by shortening their operating cycles and by reducing the risks they take in their R\&D projects. The effect of tax increases on risk taking is largely driven by firms located in states with few loss-offset opportunities, as theory would have predicted. Consistent with the interpretation that creditors use restrictive covenants to prevent firms from increasing risk ex post, we show that only firms with low financial leverage increase risk in response to tax cuts.

In addition to using a difference-in-differences regression with a comprehensive set of firmlevel and state-level control variables, we employ a battery of refinements to establish causality: including industry-by-year fixed effects to control for time-varying industry shocks, adding lead terms to confirm parallel trends, using neighboring states to control for local shocks, and controlling for other coincident state-level policy changes. Of course, the extent to which our evidence can be viewed as causal will depend on the severity of any remaining identification concerns.

As in Heider and Ljungqvist (2015), an important caveat concerns the external validity of our 
findings. The state-level tax changes in our sample are generally small in magnitude, and it is possible that firms would respond differently if the tax shocks were larger. The relatively small magnitude of our tax changes may also be the reason why we do not see firms adjusting their long-term investment decisions in response to state tax changes.

We end with a brief discussion of potential policy implications. While raising taxes can increase the government's revenue, it may have the side effect of dulling risk-taking incentives in the corporate sector, which in turn may adversely affect innovation and economic growth. Moreover, if the government wishes to encourage risk taking, our findings suggest that merely reducing tax rates is unlikely to be effective without other policy changes. 


\section{References}

Acharya, V. V., Almeida, H., Campello M., 2007. Is cash negative debt? A hedging perspective on corporate financial policies. Journal of Financial Intermediation 16, 515-554.

Acharya, V. V., Amihud, Y., Litov, L., 2011. Creditor rights and corporate risk-taking. Journal of Financial Economics 102, 150-166.

Altonji, J. G., Elder, T., Taber, C., 2005. Selection on observed and unobserved variables: Assessing the effectiveness of Catholic schools. Journal of Political Economy 113, 151184.

Asker, J., Farre-Mensa, J., Ljungqvist, A., 2015. Corporate investment and stock market listing: A puzzle? Review of Financial Studies 28, 342-390.

Bargeron, L., Lehn, K., Zutter, C. J., 2010. Sarbanes-Oxley and corporate risk-taking. Journal of Accounting and Economics 49, 34-52.

Barro, R. J., 1990. On the predictability of tax-rate changes. In: Barro, R. J., (Ed.). Macroeconomic Policy. Cambridge: Harvard University Press, 268-297.

Cassell, C. A., Huang, S. X., Manuel Sanchez, J., Stuart, M. D., 2012. Seeking safety: The relation between CEO inside debt holdings and the riskiness of firm investment and financial policies. Journal of Financial Economics 103, 588-610.

Chirinko, R., Wilson, D., 2008. State investment tax incentives: a zero-sum game? Journal of Public Economics 92, 2362-2384.

Choy, H., Lin, J., Officer, M. S., 2014. Does freezing a defined benefit pension plan affect firm risk? Journal of Accounting and Economics 57, 1-21.

Christensen, H. B., Hail, L., Leuz, C., 2016. Capital-market effects of securities regulation: Prior conditions, implementation, and enforcement. Review of Financial Studies 29, 28852924.

Coles, J. L., Daniel, N. D., Naveen, L., 2006. Managerial incentives and risk-taking. Journal of Financial Economics 79, 431-468.

Correia, M., Kang, J., Richardson, S., 2015. Does fundamental volatility help explain credit risk? Working Paper.

Dell, M., 2010. The persistent effects of Peru’s mining mita. Econometrica 78, 1863-1903.

Domar, E. D., Musgrave, R. A., 1944. Proportional income taxation and risk-taking. Quarterly Journal of Economics 58, 388-422.

Dube, A., Lester, T. W., Reich, M., 2010. Minimum wage effects across state borders: Estimates using contiguous counties. Review of Economics and Statistics 92, 945-964.

Faccio, M., Marchica, M.-T., Mura, R., 2011. Large shareholder diversification and corporate risk-taking. Review of Financial Studies 24, 3601-3641.

Farre-Mensa, J., Ljungqvist, A., 2016. Do measures of financial constraints measure financial constraints? Review of Financial Studies 29, 271-308.

Feldstein, M. S., 1969. The effect of taxation on risk-taking. Journal of Political Economy 77, 
755-764.

Gormley, T. A., Matsa, D. A., 2016. Playing it safe? Managerial preferences, risk, and agency conflicts. Journal of Financial Economics, Forthcoming.

Gormley, T. A., Matsa, D. A., Milbourn, T., 2013. CEO compensation and corporate risktaking: Evidence from a natural experiment. Journal of Accounting and Economics 56, 79101.

Gow, I., Larcker, D., Reiss, P., 2016. Causal inference in accounting research. Journal of Accounting Research 54, 477-523.

Graham, J. R., 2006. A review of taxes and corporate finance. Foundations and Trends in Finance 1, 573-691.

Graham, J. R., Rogers, D. A., 2002. Do firms hedge in response to tax incentives?. Journal of Finance 57, 815-839.

Graham, J. R., Smith, C. W., 1999. Tax incentives to hedge. Journal of Finance 54, 2241-2262.

Green, R. C., Talmor, E., 1985. The structure and incentive effects of corporate tax liabilities. Journal of Finance 40, 1095-1114.

Hall, R. E., Jorgenson, D. W., 1967. Tax policy and investment behavior. American Economic Review 57, 391-414.

Heider, F., Ljungqvist, A., 2015. As certain as debt and taxes: Estimating the tax sensitivity of leverage from state tax changes. Journal of Financial Economics 118, 684-712.

Hennessy, C., Strebulaev, I., 2015. Beyond random assignment: Credible inference of causal effects in dynamic economies. NBER Working Paper No. 20978.

Hines, J., 1998. Investment ramifications of distortionary tax subsidies. NBER Working Paper No. 6615.

Hirsch, B., Macpherson, D., 2003. Union membership and coverage database from the Current Population Survey: note. Industrial and Labor Relations Review 56, 349-354.

Holmes, T. J., 1998. The effect of state policies on the location of manufacturing: Evidence from state borders. Journal of Political Economy 106, 667-705.

Huang, R. R., 2008. Evaluating the real effect of bank branching deregulation: Comparing contiguous counties across U.S. state borders. Journal of Financial Economics 87, 678-705.

John, K., Litov, L., Yeung, B., 2008. Corporate governance and risk-taking. Journal of Finance 63, 1679-1728.

Knott, A. M., 2008. R\&D returns causality: Absorptive capacity or organizational IQ. Management Science 54, 2054-2067.

Koch, A. C., 2005. State taxation of banks and financial institutions (CA, IL, NY, TN). Arlington, VA: Tax Management Inc..

Kothari, S. P., Leone, A., Wasley, C. E., 2005. Performance matched discretionary accrual measures. Journal of Accounting and Economics 39, 163-197.

Langenmayr, D., Lester, R., 2015. Taxation and corporate risk-taking. Working Paper. 
Leuz, C., Wysocki, P. D., 2016. The economics of disclosure and financial reporting regulation: Evidence and suggestions for future research. Journal of Accounting Research 54, 525-622.

Ljungqvist, A., Smolyansky, M., 2016. To cut or not to cut? On the impact of corporate taxes on employment and income. NBER Working Paper No. 20753.

Lundholm, R., Sloan, R., 2012. Equity valuation and analysis with eVal. 3rd Edition. New York: McGraw-Hill.

Mandelker, G. N., Rhee, S. G., 1984. The impact of the degrees of operating and financial leverage on systematic risk of common stock. Journal of Financial and Quantitative Analysis 19, 45-57.

May, D. O., 1995. Do managerial motives influence firm risk reduction strategies? Journal of Finance 50, 1291-1308.

Maydew, E. L., 1997. Tax induced earnings management by firms with net operating losses. Journal of Accounting Research 35, 83-96.

Modigliani, F., Miller, M., 1958. The cost of capital, corporation finance and the theory of investment. American Economic Review 48, 261-297.

Neumark, D., Zhang, J., Wall, B., 2007. Employment dynamics and business relocation: New evidence from the National Establishment Time Series. Research in Labor Economics 26, 39-83.

Neumark, D., Grijalva, D., 2015. The employment effects of state hiring credits during and after the great recession. NBER Working Paper No. 18928.

Petersen, M., 2009. Estimating standard errors in finance panel data sets: Comparing approaches. Review of Financial Studies 22, 435-480.

Rajgopal, S., Shevlin, T., 2002. Empirical evidence on the relation between stock option compensation and risk taking. Journal of Accounting and Economics 33, 145-171.

Romer, C. D., Romer, D. H., 2010. The macroeconomic effects of tax changes: Estimates based on a new measure of fiscal shocks. American Economic Review 100, 763-801.

Scholes, M. S., Wilson, P., Wolfson, M. A., 1992. Firms’ responses to anticipated reductions in tax rates: The tax reform act of 1986. Journal of Accounting Research 30, 161-191.

Smith, C. W., Jr., Stulz, R. M., 1985. The determinants of firms' hedging policies. Journal of Financial and Quantitative Analysis, 20, 391-405.

Solow, R. M. 1956. A contribution to the theory of economic growth. Quarterly Journal of Economics, 70, 65-94.

Stiglitz, J. E., 1969. The effects of income, wealth and capital gains taxation on risk-taking. Quarterly Journal of Economics 83, 263-283.

Wilson, D., 2009. Beggar thy neighbor? The in-state, out-of-state, and aggregate effects of R\&D tax credits. Review of Economics and Statistics 91, 431-436. 


\section{Appendix A. Coincident State-Level Changes.}

\section{Panel A. Coincident State-Level Changes for Tax Rate Changes.}

This table reports state-level changes in economic quantities that coincide with either increases or cuts in state corporate income taxes and that have a plausible basis in theory to potentially affect corporate risk-taking decisions. We focus on changes in state taxes on banks and changes in state investment incentive programs (i.e., tax credits for investment, R\&D, and job creation, as well as job creation grant programs). We also report state-level changes in the length of tax loss carryback/carryforward periods that coincide with state tax rate changes. For variable definitions and details of their construction, see Appendix B.

\begin{tabular}{|c|c|c|c|}
\hline & & $\begin{array}{c}\text { Tax } \\
\text { increases }\end{array}$ & $\begin{array}{l}\text { Tax } \\
\text { cuts }\end{array}$ \\
\hline Number of tax changes & & 40 & 73 \\
\hline \multirow[t]{14}{*}{... of which coincide with } & increase in length of state carryback periods & 1 & 3 \\
\hline & cut in length of state carryback periods & 0 & 2 \\
\hline & increase in length of state carryforward periods & 0 & 4 \\
\hline & cut in length of state carryforward periods & 1 & 2 \\
\hline & increase in state tax on banks & 28 & 0 \\
\hline & cut in state tax on banks & 0 & 56 \\
\hline & increase in state investment tax credit rate & 1 & 6 \\
\hline & cut in state investment tax credit rate & 0 & 0 \\
\hline & increase in state $R \& D$ credit rate & 2 & 9 \\
\hline & cut in state $R \& D$ credit rate & 1 & 2 \\
\hline & increase in state job creation credit & 0 & 3 \\
\hline & cut in state job creation credit & 0 & 1 \\
\hline & increase in state job creation grants & 0 & 1 \\
\hline & cut in state job creation grants & 0 & 0 \\
\hline
\end{tabular}




\section{Panel B. Coincident State-Level Changes for Tax Loss Carryback Changes.}

This table reports state-level changes in economic quantities that coincide with either increases or cuts in the number of periods a state allows a company to carry back losses and that have a plausible basis in theory to potentially affect corporate risk-taking decisions. We focus on changes in state taxes on banks and changes in state investment incentive programs (i.e., tax credits for investment, $R \& D$, and job creation, as well as job creation grant programs). For variable definitions and details of their construction, see Appendix B.

\begin{tabular}{llcc}
\hline & & $\begin{array}{c}\text { Increases in } \\
\text { carrybacks }\end{array}$ & $\begin{array}{c}\text { Cuts in } \\
\text { carrybacks }\end{array}$ \\
\hline Number of carryback changes & & 36 \\
... of which coincide with & increase in state tax on banks & 15 & 0 \\
& cut in state tax on banks & 0 & 1 \\
& increase in state investment tax credit rate & 2 & 0 \\
& cut in state investment tax credit rate & 0 & 2 \\
& increase in state R\&D credit rate & 0 & 0 \\
& cut in state R\&D credit rate & 0 & 0 \\
& increase in state job creation credit & 2 & 0 \\
cut in state job creation credit & 0 & 0 \\
& increase in state job creation grants & 0 & 0 \\
\hline
\end{tabular}




\section{Panel C. Coincident State-Level Changes for Tax Loss Carryforward Changes.}

This table reports state-level changes in economic quantities that coincide with either increases or cuts in the number of periods a state allows a company to carry forward losses and that have a plausible basis in theory to potentially affect corporate risk-taking decisions. We focus on changes in state taxes on banks and changes in state investment incentive programs (i.e., tax credits for investment, $\mathrm{R} \& \mathrm{D}$, and job creation, as well as job creation grant programs). For variable definitions and details of their construction, see Appendix B.

Increases in carryforwards
Cuts in carryforwards

Number of carryforward changes

47

1

increase in state tax on banks cut in state tax on banks

increase in state investment tax credit rate cut in state investment tax credit rate

increase in state $R \& D$ credit rate cut in state $\mathrm{R} \& \mathrm{D}$ credit rate

increase in state job creation credit cut in state job creation credit

increase in state job creation grants cut in state job creation grants
10

0

1

1

0

2

0

0

0

0

$0 \quad 0$




\section{Appendix B. Variable Definitions.}

\section{Dependent variables}

$\boldsymbol{R O A}$ volatility is defined as the standard deviation of the difference between quarterly $R O A$ and $R O A$ for the same quarter of the previous year, computed over a three-year period $t$ to $t+2$ (requiring a minimum of four quarters of data). ROA (return on assets) is defined as operating income after depreciation (Compustat item oiadpq) over the book value of assets (Compustat item atq). We annualize ROA volatility by multiplying it by $\sqrt{4}$.

ROIC volatility is defined as the standard deviation of the difference between quarterly ROIC and $R O I C$ for the same quarter of the previous year, computed over a three-year period $t$ to $t+2$ (requiring a minimum of four quarters of data). ROIC (return on invested capital) is defined as operating income after depreciation (Compustat item oiadpq) over the sum of debt (Compustat items $d l t t q+d l c q$ ), minority interests (Compustat item mibtq), preferred stock (pstkq) and common stock (ceqq). We annualize ROIC volatility by multiplying it by $\sqrt{4}$.

Operating cycle is defined as the sum of the average inventory holding period and the average number of days to collect receivables minus the average number of days to pay payables. The average inventory holding period is computed as average inventory (Compustat item invt) over cost of goods sold (Compustat item cogs), multiplied by 365. The average number of days to collect receivables is computed as average accounts receivable (Compustat item rect) over sales (Compustat item sale), multiplied by 365. The average number of days to pay payables is computed as average accounts payable (Compustat item $a p$ ) over purchases (cost of goods sold + ending inventory - beginning inventory), multiplied by 365.

Days inventory is defined as the average inventory holding period, computed as average inventory (Compustat item invt) over cost of goods sold (Compustat item cogs), multiplied by 365.

Operating leverage is measured as the sensitivity of EBIT to sales (Mandelker and Rhee 1984). Specifically, it is estimated as the coefficient on the logarithm of quarterly sales in a firm-specific regression that regresses the logarithm of quarterly operating income after depreciation (Compustat item oiadpq) on the logarithm of quarterly sales (Compustat item saleq) over a three-year period from $t$ to $t+2$ (requiring a minimum of four quarters of data).

Capex is defined as net capital expenditure (Compustat item capx - sppe) over the book value of assets (Compustat item at).

$\boldsymbol{R} \boldsymbol{\& D}$ is defined as research and development expenditure (Compustat item $x r d$ ) over the book value of assets (Compustat item at). Following standard practice, we set $x r d$ equal to zero when it is missing from Compustat.

$\boldsymbol{R} \boldsymbol{Q}$ (short for research quotient) is a firm-year measure of the output elasticity of R\&D (Knott 2008), obtained from the WRDS RQ ${ }^{\mathrm{TM}}$ database. It represents the percentage increase in revenues (in year $t+1$ ) resulting from a $1 \%$ increase in R\&D (in year $t$ ), when other inputs and their elasticities are held constant.

$\underline{\text { Independent variables: Firm characteristics }}$

Firm age is defined as the Compustat age.

Firm size is defined as the book value of total assets (Compustat item at) in year 2009 real dollars (deflated using the GDP deflator available at http://www.bea.gov/national/xls/gdplev.xls).

Market/book is defined as the ratio of the market value of equity (Compustat items prcc $f \times c s h o$ ) to the book value of equity (Compustat item ceq).

Book leverage is defined as long-term debt (Compustat item dltt) over the book value of assets (Compustat item at).

Cash surplus is defined as cash from assets-in-place (Compustat items oancf $-d p c+x r d$ ) over the book value of assets (Compustat item at). 
Loss carryforward is an indicator set equal to one if the firm has positive net operating loss carryforward (Compustat item $t l c f)$, and zero otherwise.

Sales growth is defined as the log of current year sales over last year sales (Compustat item sale).

Stock return is defined as cumulated monthly returns over the 12-month period ending at the fiscal year end (measured using data from CRSP).

$\underline{\text { Independent variables: State-level characteristics }}$

GSP growth rate is the real annual growth rate in gross state product (GSP) using data obtained from the U.S. Bureau of Economic Analysis.

State unemployment rate is the state unemployment rate, obtained from the U.S. Bureau of Labor Statistics.

State tax on banks captures changes in the rate at which a state taxes financial institutions with nexus to the state. (Both a physical presence in the state and out-of-state lending to borrowers located in the state constitute nexus.) The data come from the Book of the States and state codes accessed through Lexis-Nexis.

State investment tax credit rate is the rate at which a firm can deduct capital expenditures directly from its state corporate income tax liability (in addition to the usual depreciation deductions against taxable income). Data through 2006 come from Chirinko and Wilson (2008). Data for subsequent years come from tax forms available on state Department of Revenue websites.

State $R \& D$ credit rate is the percentage of a firm's R\&D expenditures that it can deduct directly from its state corporate income tax liability (in addition to the usual deduction against taxable income). Data through 2006 come from Wilson (2009). Data for subsequent years come from tax forms available on state Department of Revenue websites.

State job creation credit is set equal to one if the state offers a tax credit in return for hiring new workers meeting certain requirements, and zero otherwise. The data come from Appendix A1 in Neumark and Grijalva (2015).

State job creation grants is set equal to one if the state offers grant payments in return for hiring new workers meeting certain requirements, and zero otherwise. The data come from Appendix A1 in Neumark and Grijalva (2015).

Democratic governor is an indicator set equal to one if the state is governed by a Democratic governor, and zero otherwise. Data come from the Congressional Quarterly (through 2008) and state election websites (after 2008).

State budget balance equals the difference between a state's general revenues and its general expenditures scaled by its general expenditures. The data come from the U.S. Census Bureau's State \& Local Finances database, available at http://www.census.gov/govs/local.

State bond rating downgrade is an indicator set equal to one if the state's credit rating is downgraded by either Standard \& Poor's or Moody's.

State union penetration is the fraction of private-sector employees in a state who belong to a labor union in year $t$. The data come from Hirsch and Macpherson (2003) as updated on their website, http://www.unionstats.com.

Tax competition is measured as the difference between a state's corporate income tax rate and the highest corporate income tax rate levied by any of the neighboring states. 


\section{Table 1. Firm-Level Summary Statistics.}

The sample consists of 64,447 firm-years for all non-financial and non-utility U.S. companies that are traded on the NYSE, Amex, or Nasdaq in fiscal years 1990 through 2011, as per the merged CRSP-Compustat Fundamentals Annual database. The table reports summary statistics for our dependent variables and the controls. For variable definitions and details of their construction, see Appendix B. All variables are winsorized 1\% in each tail.

\begin{tabular}{lrrrrr}
\hline & & & \multicolumn{3}{c}{ percentile } \\
\cline { 5 - 6 } & mean & s.d. & 25th & 50 th & 75th \\
\hline & & & & & \\
Dependent variables & & & & & \\
ROA volatility (in \%) & 6.8 & 11.0 & 2.3 & 3.8 & 7.2 \\
ROIC volatility (in \%) & 10.6 & 17.2 & 3.1 & 5.3 & 10.2 \\
operating cycle & 83.6 & 96.1 & 32.2 & 73.3 & 125.7 \\
days inventory & 75.7 & 76.8 & 12.9 & 59.7 & 108.7 \\
operating leverage & 2.5 & 3.6 & 0.9 & 1.8 & 3.4 \\
capex (in \%) & 5.4 & 6.1 & 1.7 & 3.6 & 6.9 \\
R\&D (in \%) & 5.3 & 11.8 & 0.0 & 0.1 & 5.9 \\
RQ & 10.0 & 5.4 & 7.5 & 10.0 & 12.6 \\
& & & & & \\
State characteristics & & & & & \\
GSP growth rate (in \%) & 2.7 & 2.6 & 1.1 & 2.7 & 4.2 \\
state unemployment rate (in \%) & 5.9 & 1.9 & 4.6 & 5.5 & 6.9 \\
& & & & & \\
Firm characteristics & & & & & \\
firm age & 19.6 & 13.3 & 9.0 & 15.0 & 27.0 \\
firm size (total assets, \$m) & $1,755.2$ & $4,899.7$ & 52.6 & 219.2 & 969.3 \\
market/book & 3.0 & 4.7 & 1.1 & 1.9 & 3.3 \\
book leverage & 0.162 & 0.179 & 0.002 & 0.111 & 0.267 \\
cash surplus & 0.035 & 0.199 & -0.012 & 0.050 & 0.115 \\
loss carryforward & 0.363 & 0.481 & 0.000 & 0.000 & 1.000 \\
sales growth & 0.052 & 0.339 & -0.057 & 0.050 & 0.166 \\
stock return & 0.166 & 0.744 & -0.251 & 0.040 & 0.375 \\
& & & & & \\
\hline
\end{tabular}




\section{Table 2. Effect of Tax Changes on Firm Risk.}

We estimate OLS regressions to test whether, and by how much, firms change their risk profile in response to changes in state corporate income taxes. The dependent variable change in $\log R O A$ (or ROIC) volatility is defined as the difference between $\log R O A$ (or ROIC) volatility at $t$ (i.e., computed over $t$ to $t+2$ ) and $\log R O A$ (or ROIC) volatility at $t-3$ (i.e., computed over $t-3$ to $t-1$ ). For variable definitions and details of their construction, see Appendix B. In columns 1 and 2, we use contemporaneous changes in the firm's home-state top marginal corporate income tax rate. In columns 3 and 4, we use lagged changes in the firm's home-state top marginal corporate income tax rate. Columns 5 and 6 use the contemporaneous nexus-weighted change in tax rates as defined in Eq. (2). The unit of analysis in each column is a firm-year. All specifications are estimated using OLS in first differences to remove firm fixed effects in the levels equations and include industry-by-year fixed effects to remove industry shocks. The fixed effects are not reported for brevity. Heteroskedasticity-consistent standard errors clustered at the state level are shown in italics underneath the coefficient estimates. We use ***, **, and * to denote significance at the $1 \%, 5 \%$, and $10 \%$ level (two-sided), respectively. Reflecting the signed nature of the predictions, the test for equal tax sensitivity (tax increase $=$-tax cut) is one-sided.

\begin{tabular}{|c|c|c|c|c|c|c|}
\hline & \multicolumn{6}{|c|}{ Change in $\log \ldots$} \\
\hline & $\begin{array}{c}\text { ROA } \\
\text { volatility } \\
(1)\end{array}$ & $\begin{array}{c}\text { ROIC } \\
\text { volatility } \\
(2)\end{array}$ & $\begin{array}{c}R O A \\
\text { volatility } \\
(3) \\
\end{array}$ & $\begin{array}{c}\text { ROIC } \\
\text { volatility } \\
(4)\end{array}$ & $\begin{array}{c}\text { ROA } \\
\text { volatility } \\
(5)\end{array}$ & $\begin{array}{c}\text { ROIC } \\
\text { volatility } \\
(6)\end{array}$ \\
\hline magnitude of tax increase & $\begin{array}{c}-0.019^{* * *} \\
0.007\end{array}$ & $\begin{array}{c}-0.020^{* * *} \\
0.007\end{array}$ & & & & \\
\hline magnitude of tax cut & $\begin{array}{l}0.016 \\
0.016\end{array}$ & $\begin{array}{l}0.018 \\
0.015\end{array}$ & & & & \\
\hline lagged tax increase & & & $\begin{array}{c}-0.026^{* * *} \\
0.007\end{array}$ & $\begin{array}{c}-0.019^{* *} \\
0.009\end{array}$ & & \\
\hline lagged tax cut & & & $\begin{array}{l}0.000 \\
0.015\end{array}$ & $\begin{array}{l}0.000 \\
0.017\end{array}$ & & \\
\hline nexus-weighted tax increase & & & & & $\begin{array}{c}-0.024^{* *} \\
0.009\end{array}$ & $\begin{array}{c}-0.032^{* * *} \\
0.011\end{array}$ \\
\hline nexus-weighted tax cut & & & & & $\begin{array}{l}0.014 \\
0.024\end{array}$ & $\begin{array}{l}0.017 \\
0.028\end{array}$ \\
\hline Change in ... & & & & & & \\
\hline GSP growth rate & $\begin{array}{c}-0.003^{* *} \\
0.001\end{array}$ & $\begin{array}{c}-0.003^{*} \\
0.001\end{array}$ & $\begin{array}{c}-0.003^{* *} \\
0.001\end{array}$ & $\begin{array}{c}-0.003^{*} \\
0.002\end{array}$ & $\begin{array}{c}-0.003^{* *} \\
0.001\end{array}$ & $\begin{array}{c}-0.003^{*} \\
0.001\end{array}$ \\
\hline state unemployment rate & $\begin{array}{l}0.009^{* *} \\
0.005\end{array}$ & $\begin{array}{l}0.010^{*} \\
0.006\end{array}$ & $\begin{array}{l}0.009^{*} \\
0.005\end{array}$ & $\begin{array}{l}0.009^{*} \\
0.005\end{array}$ & $\begin{array}{l}0.009^{* *} \\
0.005\end{array}$ & $\begin{array}{l}0.009^{*} \\
0.006\end{array}$ \\
\hline Lagged change in ... & & & & & & \\
\hline log firm age & $\begin{array}{c}-0.526^{* * *} \\
0.040\end{array}$ & $\begin{array}{c}-0.556^{* * *} \\
0.041\end{array}$ & $\begin{array}{c}-0.526^{* * *} \\
0.040\end{array}$ & $\begin{array}{c}-0.553^{* * *} \\
0.040\end{array}$ & $\begin{array}{c}-0.527^{* * *} \\
0.039\end{array}$ & $\begin{array}{c}-0.556^{* * *} \\
0.041\end{array}$ \\
\hline log firm size & $\begin{array}{c}-0.242^{* * *} \\
0.018\end{array}$ & $\begin{array}{c}-0.325^{* * *} \\
0.027\end{array}$ & $\begin{array}{c}-0.242^{* * *} \\
0.017\end{array}$ & $\begin{array}{c}-0.325^{* * *} \\
0.027\end{array}$ & $\begin{array}{c}-0.242^{* * *} \\
0.018\end{array}$ & $\begin{array}{c}-0.325^{* * *} \\
0.027\end{array}$ \\
\hline log market/book & $\begin{array}{l}0.123^{* * *} \\
0.007\end{array}$ & $\begin{array}{l}0.164^{* * *} \\
0.007\end{array}$ & $\begin{array}{l}0.121^{* * * *} \\
0.007\end{array}$ & $\begin{array}{l}0.163^{* * *} \\
0.008\end{array}$ & $\begin{array}{l}0.123^{* * *} \\
0.007\end{array}$ & $\begin{array}{l}0.164^{* * * *} \\
0.007\end{array}$ \\
\hline book leverage & $\begin{array}{l}-0.300^{* * * *} \\
0.032\end{array}$ & $\begin{array}{l}-0.389^{* * *} \\
0.035\end{array}$ & $\begin{array}{l}-0.301^{* * *} \\
0.034\end{array}$ & $\begin{array}{l}-0.392^{* * *} \\
0.037\end{array}$ & $\begin{array}{l}-0.300^{* * * *} \\
0.032\end{array}$ & $\begin{array}{l}-0.389^{* * * *} \\
0.035\end{array}$ \\
\hline cash surplus & $\begin{array}{c}-0.250^{* * *} \\
0.021\end{array}$ & $\begin{array}{c}-0.253^{* * *} \\
0.021\end{array}$ & $\begin{array}{c}-0.248^{* * *} \\
0.020\end{array}$ & $\begin{array}{c}-0.247^{* * *} \\
0.020\end{array}$ & $\begin{array}{c}-0.249^{* * *} \\
0.021\end{array}$ & $\begin{array}{c}-0.253^{* * *} \\
0.021\end{array}$ \\
\hline loss carryforward & $\begin{array}{l}0.018^{*} \\
0.010\end{array}$ & $\begin{array}{l}0.030^{\text {**** }} \\
0.010\end{array}$ & $\begin{array}{l}0.017^{*} \\
0.010\end{array}$ & $\begin{array}{l}0.029^{* * * *} \\
0.010\end{array}$ & $\begin{array}{l}0.018^{*} \\
0.010\end{array}$ & $\begin{array}{l}0.030^{* * *} \\
0.010\end{array}$ \\
\hline sales growth & $\begin{array}{l}0.042^{* * *} \\
0.005\end{array}$ & $\begin{array}{l}0.052^{* * *} \\
0.005\end{array}$ & $\begin{array}{l}0.042^{* * *} \\
0.005\end{array}$ & $\begin{array}{l}0.052^{* * *} \\
0.005\end{array}$ & $\begin{array}{l}0.042^{* * *} \\
0.005\end{array}$ & $\begin{array}{l}0.052^{* * *} \\
0.005\end{array}$ \\
\hline stock return & $\begin{array}{c}-0.047^{* * *} \\
0.002\end{array}$ & $\begin{array}{c}-0.055^{* * *} \\
0.003\end{array}$ & $\begin{array}{c}-0.046^{* * *} \\
0.003\end{array}$ & $\begin{array}{c}-0.054^{* * *} \\
0.003\end{array}$ & $\begin{array}{c}-0.047^{* * *} \\
0.002\end{array}$ & $\begin{array}{c}-0.055^{* * *} \\
0.003\end{array}$ \\
\hline Industry-year fixed effects & Yes & Yes & Yes & Yes & Yes & Yes \\
\hline$R^{2}$ & $21.3 \%$ & $21.0 \%$ & $21.4 \%$ & $21.1 \%$ & $21.3 \%$ & $21.0 \%$ \\
\hline Equal tax sensitivity? $(F)$ & 0.03 & 0.02 & $2.03^{*}$ & 0.74 & 0.17 & 0.25 \\
\hline No. of firms & 8,046 & 7,999 & 8,041 & 7,994 & 8,046 & 7,999 \\
\hline No. of observations & 64,447 & 64,221 & 64,435 & 64,200 & 64,447 & 64,221 \\
\hline
\end{tabular}


Table 3. Effect of Tax Changes on Risk for Firms with Low or High Leverage.

To test whether firms are constrained by their lenders from increasing risk in response to a tax cut, we partition the sample based on financial leverage (measured as of the end of the fiscal year before a tax change). Columns 1 and 3 focus on firms with book leverage below the sample median. Columns 2 and 4 focus on firms with book leverage above the sample median. For variable definitions and details of their construction, see Appendix B. The unit of analysis is a firm-year. All specifications are estimated using OLS in first differences with industry-by-year fixed effects (not shown for brevity). The tests for equal tax sensitivity across columns 1 and 2 and across columns 3 and 4 are based on fully-interacted models. Reflecting the signed nature of the predictions, the tests for equal tax sensitivity are one-sided. Heteroskedasticity-consistent standard errors clustered at the state level are shown in italics underneath the coefficient estimates. We use ${ }^{* * *}, * *$, and $*$ to denote significance at the $1 \%, 5 \%$, and $10 \%$ level (two-sided), respectively.

\begin{tabular}{|c|c|c|c|c|}
\hline & \multicolumn{4}{|c|}{ Change in $\log \ldots$} \\
\hline & \multicolumn{2}{|c|}{ ROA volatility } & \multicolumn{2}{|c|}{ ROIC volatility } \\
\hline & $\begin{array}{c}\text { Low } \\
\text { leverage } \\
(1)\end{array}$ & $\begin{array}{c}\text { High } \\
\text { leverage } \\
\text { (2) }\end{array}$ & $\begin{array}{c}\text { Low } \\
\text { leverage } \\
(3)\end{array}$ & $\begin{array}{c}\text { High } \\
\text { leverage } \\
\text { (4) }\end{array}$ \\
\hline magnitude of tax increase & $\begin{array}{l}-0.026^{* * *} \\
0.009\end{array}$ & $\begin{array}{l}-0.024^{* * *} \\
0.008\end{array}$ & $\begin{array}{c}-0.032^{* *} \\
0.012\end{array}$ & $\begin{array}{l}-0.022^{* *} \\
0.009\end{array}$ \\
\hline magnitude of tax cut & $\begin{array}{l}0.063^{* * *} \\
0.018\end{array}$ & $\begin{array}{c}-0.019 \\
0.019\end{array}$ & $\begin{array}{l}0.072^{* * *} \\
0.014\end{array}$ & $\begin{array}{c}-0.019 \\
0.023\end{array}$ \\
\hline Controls & Yes & Yes & Yes & Yes \\
\hline Industry-year fixed effects & Yes & Yes & Yes & Yes \\
\hline$R^{2}$ & $25.6 \%$ & $31.1 \%$ & $25.3 \%$ & $31.1 \%$ \\
\hline \multicolumn{5}{|l|}{ Equal tax sensitivity? $(F)$} \\
\hline Tax increases: (1) vs. (2) or (3) vs. (4) & \multirow{2}{*}{\multicolumn{2}{|c|}{$\begin{array}{c}0.03 \\
15.44^{* * * *}\end{array}$}} & \multicolumn{2}{|c|}{0.41} \\
\hline Tax cuts: (1) vs. (2) or (3) vs. (4) & & & & $91^{* * *}$ \\
\hline No. of firms & 5,769 & 5,467 & 5,723 & 5,441 \\
\hline No. of observations & 32,223 & 32,224 & 32,105 & 32,106 \\
\hline
\end{tabular}




\section{Table 4. Testing for Pre-Trends, Delays, and Post-Event Reversals.}

To investigate possible pre-trends, delays, and reversals, we include lead and lag terms in the baseline regressions shown in Table 2, columns 1 and 2. Recall that the change in ROA volatility or ROIC volatility compares earnings volatility in the period $t$ to $t+2$ to earnings volatility in the period $t-3$ to $t-1$. Accordingly, we use leads dated $t+3$ and lags dated $t-3$ to avoid inducing a mechanical correlation between the dependent variable and the lead or lag term. For variable definitions and details of their construction, see Appendix B. The unit of analysis is a firm-year. All specifications are estimated using OLS in first differences to remove firm fixed effects in the levels equations and include industry-by-year fixed effects to remove industry shocks. The full set of controls (as in Table 2) and fixed effects are included but not reported for brevity. Heteroskedasticity-consistent standard errors clustered at the state level are shown in italics underneath the coefficient estimates. We use ***, **, and * to denote significance at the $1 \%, 5 \%$, and $10 \%$ level (two-sided), respectively.

\begin{tabular}{|c|c|c|}
\hline & \multicolumn{2}{|c|}{ Change in $\log . .}$. \\
\hline & $\begin{array}{c}R O A \\
\text { volatility } \\
(1)\end{array}$ & $\begin{array}{c}\text { ROIC } \\
\text { volatility } \\
(2)\end{array}$ \\
\hline magnitude of tax increase at $t=+3$ & -0.001 & -0.005 \\
\hline magnitude of tax increase at $t=0$ & $\begin{array}{c}0.025 \\
-0.019^{* *} \\
0.009\end{array}$ & $\begin{array}{c}0.028 \\
-0.017^{* *} \\
0.008\end{array}$ \\
\hline magnitude of tax increase at $t=-3$ & $\begin{array}{c}-0.016^{*} \\
0.008\end{array}$ & $\begin{array}{c}-0.014 \\
0.008\end{array}$ \\
\hline magnitude of tax cut at $t=+3$ & $\begin{array}{r}-0.007 \\
0.011\end{array}$ & $\begin{array}{l}0.007 \\
0.013\end{array}$ \\
\hline magnitude of tax cut at $t=0$ & $\begin{array}{l}0.018 \\
0.014\end{array}$ & $\begin{array}{l}0.018 \\
0.014\end{array}$ \\
\hline magnitude of tax cut at $t=-3$ & $\begin{array}{r}-0.001 \\
0.014\end{array}$ & $\begin{array}{r}-0.002 \\
0.018\end{array}$ \\
\hline Controls & Yes & Yes \\
\hline Industry-year fixed effects & Yes & Yes \\
\hline$R^{2}$ & $24.4 \%$ & $23.6 \%$ \\
\hline No. of firms & 6,183 & 6,171 \\
\hline No. of observations & 47,966 & 47,879 \\
\hline
\end{tabular}


Table 5. Potential Confounds: Local Business Cycle Effects, Other Tax Changes, and Determinants of Tax Rate Changes.

States may change corporate tax rates, and firms may change their risk profile, in response to unobserved changes in local business conditions. To examine this potential confound, we restrict the set of control firms to those located in a neighboring state, thus excluding far-away states (i.e., firms in states that neither experience a tax change nor border a state that does are excluded). This means that we drop observations for states that are treated in another year but are not the neighbor of a treated state in the current year. This reduces the sample compared to the baseline models shown in Table 2. To address concerns stemming from the fact that corporate tax changes occasionally coincide with changes in state taxes on bank profits or in investment incentive programs (i.e., tax credits for investment, R\&D, and job creation), columns 3 and 4 control explicitly for these concurrent changes. In columns 5 and 6 , we further control for local political forces and economic conditions that may influence whether a state changes its corporate tax rate (namely, the governor's political affiliation, the election cycle, the state's budget balance, ratings downgrades, unemployment, growth, union penetration, and tax competition with neighboring states). All specifications are estimated using OLS in first differences with industry-by-year fixed effects and group-year fixed effects, where a treated state and its neighboring states are coded as a group. The full set of controls (as in Table 2) and fixed effects are included but not reported for brevity. For variable definitions and details of their construction, see Appendix B. Heteroskedasticity-consistent standard errors clustered at the state level are shown in italics underneath the coefficient estimates. We use ***,**, and * to denote significance at the $1 \%, 5 \%$, and $10 \%$ level (two-sided), respectively. Reflecting the signed nature of the predictions, the test for equal tax sensitivity (tax increase $=$-tax cut) is one-sided.

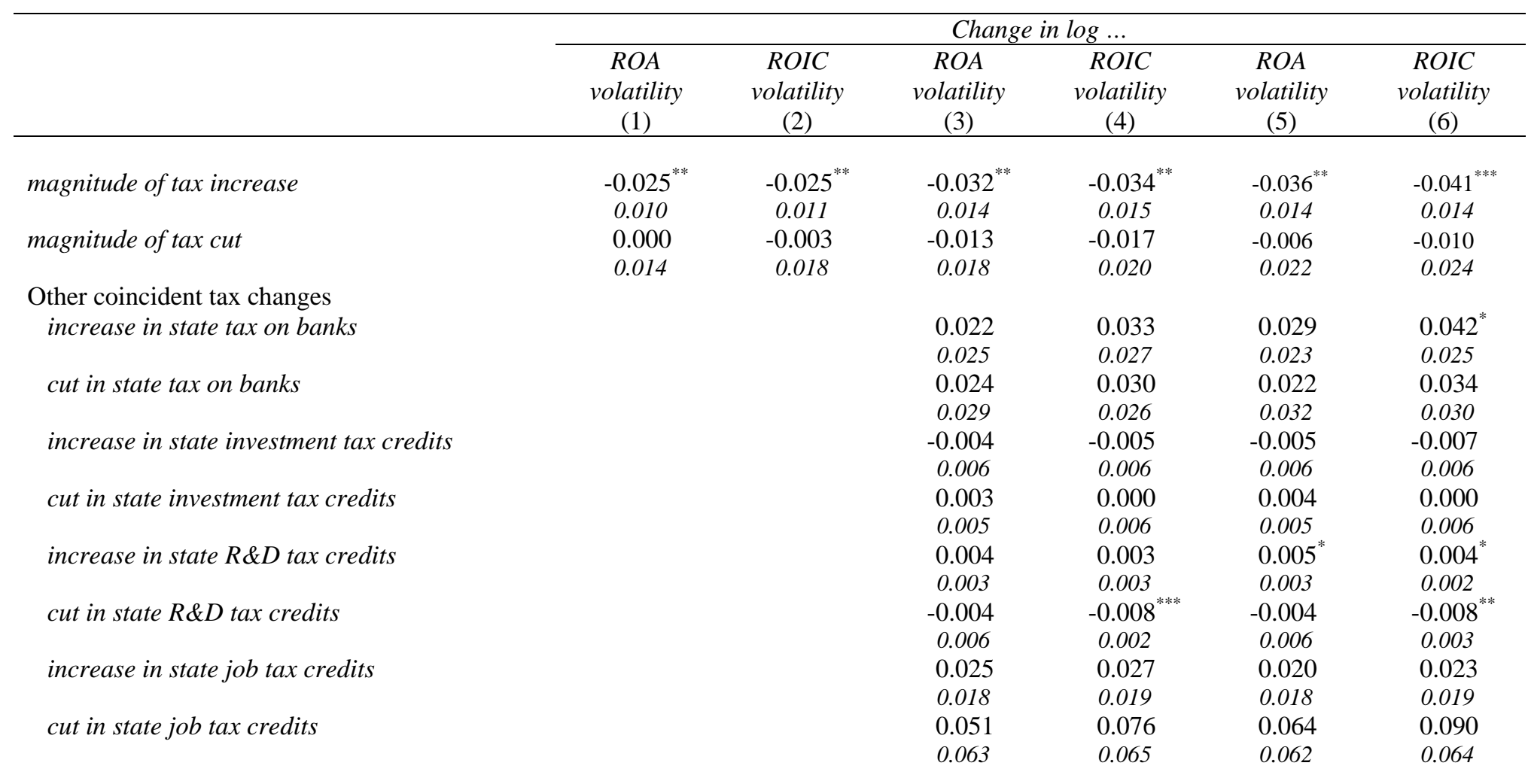


Political conditions

Lagged change in Democratic governor

$=1$ if one year to next gubernatorial election

$=1$ if two years to next gubernatorial election

$=1$ if three years to next gubernatorial election

Economic conditions

Lagged change in state budget balance

$=1$ if state bond rating downgraded in year $t-1$

Lagged change in GSP growth rate

Lagged change in state unemployment rate

Lagged change in state union penetration

Tax competition

Lagged change in state's tax rate relative to

highest tax rate among its neighboring states

$0.046^{* * *} \quad 0.034^{* *}$

0.015

0.015

$-0.014$

$0.018-0.020$

$0.004 \quad 0.008$

$0.013-0.014$

$-0.032-0.034$

$0.020 \quad 0.019$

$0.120 \quad 0.168$

$0.139-0.145$

$-0.017 \quad-0.018$

$0.021 \quad 0.023$

$0.002 \quad 0.004$

$0.003 \quad 0.003$

$-0.016^{*} \quad-0.014$

$0.008 \quad 0.011$

$-0.005 \quad-0.005$

$0.006 \quad 0.006$

Controls

Industry-year fixed effects

Group-year fixed effects

$R^{2}$

Equal tax sensitivity? $(F)$

No. of firms

No. of observations

Yes
Yes
Yes
$28.8 \%$
1.44
6,547
29,498

0.000

0.006

0.004

29,498

Yes
Yes
Yes
$29.0 \%$
$6.65^{* * *}$
6,586
29,613

Yes
Yes
Yes
$28.8 \%$
$4.35^{* *}$
6,547
29,498

Yes

Yes

Yes

$29.1 \%$

$4.16^{* *}$

6,586

29,613

0.004

Yes

Yes

Yes

$28.8 \%$

3.51

6,547

29,498 


\section{Table 6. Anticipation Effects.}

If state tax rate changes are anticipated, measured treatment responses to realized tax rate changes may not capture causal effects (Hennessy and Strebulaev 2015). To address this concern, we exclude firms headquartered in states whose tax rate changes are likely to be anticipated. Ljungqvist and Smolyansky (2015) test whether state tax rates follow a Martingale (which implies that changes in tax rates are unpredictable). Based on their findings, columns 1 and 2 exclude firms headquartered in Connecticut or Massachusetts while columns 3 and 4 exclude firms headquartered in New England (i.e., Connecticut, Maine, Massachusetts, New Hampshire, Rhode Island, or Vermont). Heider and Ljungqvist (2015) examine the political economy events surrounding all state tax changes affecting at least 100 firms, using a "narrative approach" to identify potentially anticipated tax changes. Based on their findings, columns 5 and 6 exclude firms headquartered in Colorado, Connecticut, Minnesota, or New York. For variable definitions and details of their construction, see Appendix B. The unit of analysis in each column is a firmyear. All specifications are estimated using OLS in first differences to remove firm fixed effects in the levels equations and include industry-by-year fixed effects to remove industry shocks. The full set of controls (as in Table 2) and fixed effects are included but not reported for brevity. Heteroskedasticity-consistent standard errors clustered at the state level are shown in italics underneath the coefficient estimates. We use ***, **, and * to denote significance at the 1\%, 5\%, and 10\% level (two-sided), respectively.

\begin{tabular}{|c|c|c|c|c|c|c|}
\hline & \multicolumn{6}{|c|}{ Change in $\log . .}$. \\
\hline & $\begin{array}{c}\text { ROA } \\
\text { volatility } \\
(1)\end{array}$ & $\begin{array}{c}\text { ROIC } \\
\text { volatility } \\
(2)\end{array}$ & $\begin{array}{c}\text { ROA } \\
\text { volatility } \\
\text { (3) }\end{array}$ & $\begin{array}{c}\text { ROIC } \\
\text { volatility } \\
(4)\end{array}$ & $\begin{array}{c}\text { ROA } \\
\text { volatility } \\
\text { (5) }\end{array}$ & $\begin{array}{c}\text { ROIC } \\
\text { volatility } \\
(6)\end{array}$ \\
\hline \multirow[t]{2}{*}{ magnitude of tax increase } & $-0.016^{* *}$ & $-0.018^{* *}$ & $-0.014^{* *}$ & $-0.017^{* *}$ & $-0.016^{* *}$ & $-0.019^{* *}$ \\
\hline & 0.006 & 0.008 & 0.006 & 0.007 & 0.007 & 0.008 \\
\hline \multirow[t]{2}{*}{ magnitude of tax cut } & 0.003 & 0.009 & 0.006 & 0.012 & -0.012 & -0.009 \\
\hline & 0.021 & 0.022 & 0.022 & 0.023 & 0.014 & 0.014 \\
\hline Controls & Yes & Yes & Yes & Yes & Yes & Yes \\
\hline Industry-year fixed effects & Yes & Yes & Yes & Yes & Yes & Yes \\
\hline$R^{2}$ & $22.1 \%$ & $21.9 \%$ & $22.2 \%$ & $22.0 \%$ & $23.3 \%$ & $23.0 \%$ \\
\hline No. of firms & 7,433 & 7,391 & 7,363 & 7,321 & 6,685 & 6,652 \\
\hline No. of observations & 59,130 & 58,915 & 58,476 & 58,263 & 52,699 & 52,511 \\
\hline
\end{tabular}




\section{Table 7. Effect of Tax Changes on Operational and Investment Choices.}

We estimate OLS regressions to test whether, and by how much, firms change their operational and investment policies in response to changes in state corporate income taxes. Panel A focuses on a firm's operational choices. The dependent variable change in operating cycle (or days inventory) is defined as the difference between operating cycle (or days inventory) at time $t$ and operating cycle (or days inventory) at $t-1$. The dependent variable change in operating leverage is defined as the difference between operating leverage at time $t$ (i.e., computed over $t$ to $t+2$ ) and operating leverage at $t-3$ (i.e., computed over $t-3$ to $t-1$ ). Panel B focuses on a firm's investment choices. To investigate possible pre-trends, delays, and reversals, we include lead and lag terms in the regressions. The dependent variable change in capex (or $R \& D, R Q$ ) is defined as the difference between capex (or $R \& D, R Q$ ) at time $t$ and capex (or $R \& D, R Q$ ) at $t-1$. In both panels, columns 1 to 3 use changes in the firm's home-state corporate income tax rate while columns 4 to 6 use the nexus-weighted change in tax rates as defined in Eq. (2). For variable definitions and details of their construction, see Appendix B. The unit of analysis in each column is a firm-year. All specifications are estimated using OLS in first differences to remove firm fixed effects in the levels equations and include industry-by-year fixed effects to remove industry shocks. We include the same controls and fixed effects as in Table 2. These are not reported for brevity. Heteroskedasticity-consistent standard errors clustered at the state level are shown in italics underneath the coefficient estimates. We use ${ }^{* * *}, * *$, and * to denote significance at the $1 \%, 5 \%$, and $10 \%$ level (two-sided), respectively.

\section{Panel A. Effect of Tax Changes on Operational Choices.}

\begin{tabular}{|c|c|c|c|c|c|c|}
\hline & \multicolumn{6}{|c|}{ Change in ... } \\
\hline & $\begin{array}{l}\text { operating } \\
\text { cycle } \\
\text { (1) }\end{array}$ & $\begin{array}{c}\text { days } \\
\text { inventory } \\
\text { (2) }\end{array}$ & $\begin{array}{l}\text { operating } \\
\text { leverage } \\
\text { (3) }\end{array}$ & $\begin{array}{c}\text { operating } \\
\text { cycle } \\
\text { (4) }\end{array}$ & $\begin{array}{c}\text { days } \\
\text { inventory } \\
\text { (5) }\end{array}$ & $\begin{array}{c}\text { operating } \\
\text { leverage } \\
\text { (6) }\end{array}$ \\
\hline magnitude of tax increase & $\begin{array}{c}-1.702^{* * *} \\
0.379\end{array}$ & $\begin{array}{c}-0.724^{*} \\
0.375\end{array}$ & $\begin{array}{l}0.078 \\
0.099\end{array}$ & & & \\
\hline magnitude of tax cut & $\begin{array}{r}-0.030 \\
0.956\end{array}$ & $\begin{array}{c}-0.246 \\
0.755\end{array}$ & $\begin{array}{l}0.173 \\
0.135\end{array}$ & & & \\
\hline nexus-weighted tax increase & & & & $\begin{array}{l}-3.052^{* *} \\
1.163\end{array}$ & $\begin{array}{l}-1.473^{* *} \\
0.559\end{array}$ & $\begin{array}{l}0.077 \\
0.177\end{array}$ \\
\hline nexus-weighted tax cut & & & & $\begin{array}{r}-0.787 \\
1.431\end{array}$ & $\begin{array}{c}-0.134 \\
1.014\end{array}$ & $\begin{array}{l}0.158 \\
0.193\end{array}$ \\
\hline Controls & Yes & Yes & Yes & Yes & Yes & Yes \\
\hline Industry-year fixed effects & Yes & Yes & Yes & Yes & Yes & Yes \\
\hline$R^{2}$ & $10.1 \%$ & $11.5 \%$ & $14.9 \%$ & $10.1 \%$ & $11.5 \%$ & $14.9 \%$ \\
\hline No. of firms & 7,952 & 7,981 & 6,105 & 7,952 & 7,981 & 6,105 \\
\hline No. of observations & 63,472 & 63,881 & 49,707 & 63,472 & 63,881 & 49,707 \\
\hline
\end{tabular}


Panel B. Effect of Tax Changes on Investment Choices.

\begin{tabular}{|c|c|c|c|c|c|c|}
\hline & \multicolumn{6}{|c|}{ Change in ... } \\
\hline & capex & $R \& D$ & $R Q$ & capex & $R \& D$ & $R Q$ \\
\hline & \multicolumn{3}{|c|}{ Home-state tax changes } & \multicolumn{3}{|c|}{ Nexus-weighted tax changes } \\
\hline & (1) & $(2)$ & $(3)$ & (4) & $(5)$ & $(6)$ \\
\hline \multirow[t]{2}{*}{ magnitude of tax increase at $t=+1$} & 0.000 & 0.000 & -0.121 & 0.000 & 0.001 & -0.114 \\
\hline & 0.001 & 0.001 & 0.114 & 0.001 & 0.001 & 0.110 \\
\hline \multirow[t]{2}{*}{ magnitude of tax increase at $t=0$} & 0.000 & -0.001 & -0.049 & -0.001 & -0.001 & -0.098 \\
\hline & 0.001 & 0.001 & 0.089 & 0.001 & 0.001 & 0.113 \\
\hline \multirow[t]{2}{*}{ magnitude of tax increase at $t=-1$} & 0.000 & 0.000 & $-0.167^{*}$ & 0.000 & 0.000 & $-0.231^{*}$ \\
\hline & 0.001 & 0.000 & 0.089 & 0.001 & 0.001 & 0.123 \\
\hline \multirow[t]{2}{*}{ magnitude of tax increase at $t=-2$} & 0.000 & 0.001 & -0.085 & 0.001 & 0.001 & -0.005 \\
\hline & 0.000 & 0.001 & 0.099 & 0.001 & 0.001 & 0.109 \\
\hline \multirow[t]{2}{*}{ magnitude of tax increase at $t=-3$} & 0.001 & -0.001 & $-0.155^{*}$ & 0.002 & -0.001 & $-0.231^{* *}$ \\
\hline & 0.001 & 0.001 & 0.081 & 0.001 & 0.001 & 0.113 \\
\hline \multirow[t]{2}{*}{ magnitude of tax cut at $t=+1$} & 0.000 & 0.001 & 0.126 & -0.001 & 0.002 & 0.227 \\
\hline & 0.001 & 0.002 & 0.130 & 0.001 & 0.002 & 0.169 \\
\hline \multirow[t]{2}{*}{ magnitude of tax cut at $t=0$} & -0.001 & -0.003 & -0.058 & 0.000 & -0.004 & 0.002 \\
\hline & 0.001 & 0.002 & 0.122 & 0.002 & 0.003 & 0.128 \\
\hline \multirow[t]{2}{*}{ magnitude of tax cut at $t=-1$} & 0.000 & 0.002 & -0.009 & -0.001 & 0.003 & -0.140 \\
\hline & 0.001 & 0.001 & 0.117 & 0.001 & 0.002 & 0.133 \\
\hline \multirow[t]{2}{*}{ magnitude of tax cut at $t=-2$} & 0.000 & -0.001 & -0.016 & 0.000 & -0.002 & -0.035 \\
\hline & 0.001 & 0.001 & 0.082 & 0.001 & 0.002 & 0.135 \\
\hline \multirow{2}{*}{ magnitude of tax cut at $t=-3$} & 0.001 & 0.001 & -0.146 & 0.002 & 0.001 & -0.184 \\
\hline & 0.001 & 0.002 & 0.117 & 0.001 & 0.003 & 0.144 \\
\hline Controls & Yes & Yes & Yes & Yes & Yes & Yes \\
\hline Industry-year fixed effects & Yes & Yes & Yes & Yes & Yes & Yes \\
\hline$R^{2}$ & $16.7 \%$ & $8.0 \%$ & $29.5 \%$ & $16.7 \%$ & $8.0 \%$ & $29.5 \%$ \\
\hline No. of firms & 7,323 & 7,379 & 3,771 & 7,323 & 7,379 & 3,771 \\
\hline No. of observations & 57,747 & 58,498 & 28,833 & 57,747 & 58,498 & 28,833 \\
\hline
\end{tabular}




\section{Table 8. Heterogeneous Treatment Effects.}

Tax loss carryback and carryforward rules dampen the impact of corporate income tax rate changes on firm risk. To test this, we partition sample firms based on the tax loss carryback and carryforward rules of their headquarter state. Columns 1 and 3 include firms headquartered in a state that (1) does not allow losses to be carried back and (2) does not permit losses to be carried forward for more than 10 years. Columns 2 and 4 include only the remaining sample firms. For variable definitions and details of their construction, see Appendix B. The unit of analysis is a firm-year. All specifications are estimated using OLS in first differences with industry-by-year fixed effects (not shown for brevity). The tests for equal tax sensitivity across columns 1 and 2 and across columns 3 and 4 are based on fullyinteracted models. Reflecting the signed nature of the predictions, the tests for equal tax sensitivity are one-sided. Heteroskedasticity-consistent standard errors clustered at the state level are shown in italics underneath the coefficient estimates. We use $* * *, * *$, and $*$ to denote significance at the $1 \%, 5 \%$, and $10 \%$ level (two-sided), respectively.

\begin{tabular}{|c|c|c|c|c|}
\hline & \multicolumn{4}{|c|}{ Change in $\log \ldots$} \\
\hline & \multicolumn{2}{|c|}{ ROA volatility } & \multicolumn{2}{|c|}{ ROIC volatility } \\
\hline & $\begin{array}{c}\text { Low loss } \\
\text { offset ability } \\
(1)\end{array}$ & $\begin{array}{c}\text { High loss } \\
\text { offset ability } \\
(2)\end{array}$ & $\begin{array}{c}\text { Low loss } \\
\text { offset ability } \\
\text { (3) }\end{array}$ & $\begin{array}{c}\text { High loss } \\
\text { offset ability } \\
(4)\end{array}$ \\
\hline magnitude of tax increase & $\begin{array}{c}-0.026^{* *} \\
0.009\end{array}$ & $\begin{array}{r}-0.010 \\
0.012\end{array}$ & $\begin{array}{c}-0.033^{* * *} \\
0.011\end{array}$ & $\begin{array}{r}-0.004 \\
0.016\end{array}$ \\
\hline magnitude of tax cut & $\begin{array}{l}0.009 \\
0.022\end{array}$ & $\begin{array}{l}0.012 \\
0.017\end{array}$ & $\begin{array}{l}0.017 \\
0.019\end{array}$ & $\begin{array}{l}0.014 \\
0.019\end{array}$ \\
\hline $\begin{array}{l}\text { Controls } \\
\text { Industry-year fixed effects } \\
R^{2} \\
\text { Equal tax sensitivity? }(F)\end{array}$ & $\begin{array}{r}\text { Yes } \\
\text { Yes } \\
29.8 \%\end{array}$ & $\begin{array}{r}\text { Yes } \\
\text { Yes } \\
26.9 \%\end{array}$ & $\begin{array}{r}\text { Yes } \\
\text { Yes } \\
28.8 \%\end{array}$ & $\begin{array}{r}\text { Yes } \\
\text { Yes } \\
26.8 \%\end{array}$ \\
\hline Tax increases: (1) vs. (2) or (3) vs. (4) & \multicolumn{2}{|c|}{1.18} & \multicolumn{2}{|c|}{$2.10^{*}$} \\
\hline No. of firms & 4,221 & 5,757 & 4,203 & 5,716 \\
\hline No. of observations & 26,005 & 38,442 & 25,914 & 38,297 \\
\hline
\end{tabular}




\section{Table 9. Effect of Changes in Loss Carryback/Carryforward Rules on Firm Risk.}

We estimate OLS regressions to test whether, and by how much, firms change their risk profile in response to changes in state tax loss carryback/carryforward rules. Panel A focuses on the change in the number of years a loss can be carried back or forward in a firm's headquarter state. Panel B focuses on the nexus-weighted change in the number of years a loss can be carried back or forward in the states a firm has nexus with. Both increases and reductions are measured in absolute terms. For variable definitions and details of their construction, see Appendix B. The unit of analysis is a firm-year. All specifications are estimated using OLS in first differences to remove firm fixed effects in the levels equations and include industry-by-year fixed effects to remove industry shocks. The full set of controls (as in Table 2) and fixed effects are not reported for brevity. Heteroskedasticity-consistent standard errors clustered at the state level are shown in italics underneath the coefficient estimates. We use $* * *$, $* *$, and $*$ to denote significance at the $1 \%, 5 \%$, and $10 \%$ level (two-sided), respectively. Reflecting the signed nature of the predictions, the test for equal tax sensitivity is one-sided.

\section{Panel A. Home-State Rule Changes.}

\begin{tabular}{|c|c|c|c|c|}
\hline & \multicolumn{4}{|c|}{ Change in $\log \ldots$} \\
\hline & $\begin{array}{c}R O A \\
\text { volatility } \\
(1)\end{array}$ & $\begin{array}{c}\text { ROIC } \\
\text { volatility } \\
(2)\end{array}$ & $\begin{array}{c}R O A \\
\text { volatility } \\
\text { (3) }\end{array}$ & $\begin{array}{c}\text { ROIC } \\
\text { volatility } \\
(4)\end{array}$ \\
\hline increase in length of carryback period & 0.016 & 0.022 & 0.016 & 0.022 \\
\hline & 0.014 & 0.016 & 0.014 & 0.016 \\
\hline reduction in length of carryback period & $-0.023^{* * *}$ & $-0.019^{* *}$ & $-0.023^{* * *}$ & $-0.019^{* *}$ \\
\hline increase in length of carryforward period & $\begin{array}{l}0.002^{* *} \\
0.001\end{array}$ & $\begin{array}{l}0.003^{* * *} \\
0.001\end{array}$ & $0.002^{* *}$ & $\begin{array}{l}0.003^{* * * *} \\
0.001\end{array}$ \\
\hline reduction in length of carryforward period & $\begin{array}{l}0.001 \\
0.001\end{array}$ & $\begin{array}{l}0.001 \\
0.001\end{array}$ & $\begin{array}{l}0.001 \\
0.001\end{array}$ & $\begin{array}{l}0.001 \\
0.001\end{array}$ \\
\hline magnitude of tax increase & & & $\begin{array}{c}-0.019^{* * *} \\
0.007\end{array}$ & $\begin{array}{c}-0.020^{* * *} \\
0.007\end{array}$ \\
\hline magnitude of tax cut & & & $\begin{array}{l}0.014 \\
0.016\end{array}$ & $\begin{array}{l}0.015 \\
0.016\end{array}$ \\
\hline Controls & Yes & Yes & Yes & Yes \\
\hline Industry-year fixed effects & Yes & Yes & Yes & Yes \\
\hline$R^{2}$ & $21.3 \%$ & $21.0 \%$ & $21.3 \%$ & $21.0 \%$ \\
\hline Equal tax sensitivity? $(F)$ & & & & \\
\hline increase in carryback = -reduction in carryback & 0.24 & 0.03 & 0.23 & 0.04 \\
\hline increase in carryforward = -reduction in carryforward & $4.95^{* *}$ & $5.49^{* *}$ & $4.03^{* *}$ & $4.66^{* *}$ \\
\hline reduction in carryback = -increase in carryforward & $8.02^{* * *}$ & $3.89^{* *}$ & $8.21^{* * *}$ & $3.93^{* *}$ \\
\hline No. of firms & 8,046 & 7,999 & 8,046 & 7,999 \\
\hline No. of observations & 64,447 & 64,211 & 64,447 & 64,211 \\
\hline
\end{tabular}


Panel B. Nexus-Weighted Rule Changes.

\begin{tabular}{|c|c|c|c|c|}
\hline & \multicolumn{4}{|c|}{ Change in $\log \ldots$} \\
\hline & $\begin{array}{c}R O A \\
\text { volatility } \\
(1)\end{array}$ & $\begin{array}{c}\text { ROIC } \\
\text { volatility } \\
(2)\end{array}$ & $\begin{array}{c}R O A \\
\text { volatility } \\
(3)\end{array}$ & $\begin{array}{c}\text { ROIC } \\
\text { volatility } \\
(4) \\
\end{array}$ \\
\hline \multirow[t]{2}{*}{ nexus-weighted increase in carryback period } & 0.025 & 0.038 & 0.025 & 0.038 \\
\hline & 0.024 & 0.028 & 0.024 & 0.028 \\
\hline \multirow[t]{2}{*}{ nexus-weighted reduction in carryback period } & $-0.035^{* * *}$ & $-0.028^{* * *}$ & $-0.035^{* * *}$ & $-0.028^{* * *}$ \\
\hline & 0.010 & 0.010 & 0.010 & 0.010 \\
\hline \multirow[t]{2}{*}{ nexus-weighted increase in carryforward period } & 0.002 & $0.003^{* *}$ & 0.002 & $0.003^{*}$ \\
\hline & 0.002 & 0.001 & 0.002 & 0.001 \\
\hline \multirow[t]{2}{*}{ nexus-weighted reduction in carryforward period } & 0.000 & 0.000 & 0.000 & 0.000 \\
\hline & 0.002 & 0.002 & 0.002 & 0.002 \\
\hline \multirow[t]{2}{*}{ nexus-weighted tax increase } & & & $-0.024^{* *}$ & $-0.031^{* * *}$ \\
\hline & & & 0.009 & 0.011 \\
\hline \multirow{2}{*}{ nexus-weighted tax cut } & & & 0.012 & 0.015 \\
\hline & & & 0.024 & 0.028 \\
\hline Controls & Yes & Yes & Yes & Yes \\
\hline Industry-year fixed effects & Yes & Yes & Yes & Yes \\
\hline$R^{2}$ & $21.3 \%$ & $21.0 \%$ & $21.3 \%$ & $21.0 \%$ \\
\hline \multicolumn{5}{|l|}{ Equal tax sensitivity? $(F)$} \\
\hline increase in carryback = -reduction in carryback & 0.22 & 0.13 & 0.21 & 0.15 \\
\hline increase in carryforward $=$-reduction in carryforward & 0.52 & 0.84 & 0.47 & 0.76 \\
\hline reduction in carryback = -increase in carryforward & $10.56^{* * *}$ & $5.70^{* *}$ & $10.65^{* * *}$ & $5.70^{* *}$ \\
\hline No. of firms & 8,046 & 7,999 & 8,046 & 7,999 \\
\hline No. of observations & 64,447 & 64,211 & 64,447 & 64,211 \\
\hline
\end{tabular}




\section{ONLINE APPENDIX}

(NOT INTENDED FOR PUBLICATION) 


\section{Table A.1. List of Changes in State Corporate Income Tax Rates.}

\section{Panel A. List of Tax Increases.}

This table lists all U.S. state corporate income tax increases in calendar years 1989-2012 affecting firms in fiscal years 1990-2011. In states with more than one tax bracket, we report the change to the top bracket. Tax changes are identified from the Tax Foundation (an abbreviated version of which is available at http://www.taxfoundation.org), the Book of the States, a search of the "Current Corporate Income Tax Developments" feature published periodically in the Journal of State Taxation, and state tax codes accessed through Lexis-Nexis.

\begin{tabular}{|c|c|c|c|}
\hline State & Year & Description & $\begin{array}{r}\text { No. of } \\
\text { affected } \\
\text { sample firms } \\
\end{array}$ \\
\hline IL & 1989 & Increase in top corporate income tax rate from $4 \%$ to $4.8 \%$ & 6 \\
\hline KY & 1989 & Increase in top corporate income tax rate from $7.25 \%$ to $8 \%$ & 7 \\
\hline NJ & 1989 & Introduction of $0.375 \%$ tax surcharge & 7 \\
\hline RI & 1989 & Increase in top corporate income tax rate from $8 \%$ to $9 \%$ & 7 \\
\hline CT & 1990 & Introduction of $20 \%$ tax surcharge, increasing top marginal tax rate from $11.5 \%$ to $13.8 \%$ & 64 \\
\hline MO & 1990 & Increase in top corporate income tax rate from $5 \%$ to $6.5 \%$ & 34 \\
\hline MT & 1990 & Introduction of $5 \%$ tax surcharge on tax liability & 2 \\
\hline $\mathrm{NE}$ & 1990 & Increase in top corporate income tax rate from $6.65 \%$ to $7.24 \%$ & 5 \\
\hline OK & 1990 & Increase in top corporate income tax rate from $5 \%$ to $6 \%$ & 27 \\
\hline AR & 1991 & Increase in top corporate income tax rate from $6 \%$ to $6.5 \%$ & 14 \\
\hline ME & 1991 & Introduction of $10 \%$ tax surcharge on tax liability & 3 \\
\hline NC & 1991 & $\begin{array}{l}\text { Increase in top corporate income tax rate from } 7 \% \text { to } 7.75 \% \text { and introduction of } 4 \% \text { tax } \\
\text { surcharge on tax liability }\end{array}$ & 53 \\
\hline NE & 1991 & $\begin{array}{l}\text { Increase in top corporate income tax rate from } 7.24 \% \text { to } 7.81 \% \text { and introduction of } 15 \% \text { tax } \\
\text { surcharge on tax liability }\end{array}$ & 9 \\
\hline PA & 1991 & Increase in top corporate income tax rate from $8.5 \%$ to $12.25 \%$ & 132 \\
\hline RI & 1991 & Introduction of $11 \%$ tax surcharge on tax liability & 12 \\
\hline DC & 1992 & Introduction of $2.5 \%$ surcharge on tax liability & 4 \\
\hline KS & 1992 & Increase in top corporate income tax rate (including surcharge) from $6.75 \%$ to $7.35 \%$ & 19 \\
\hline KY & 1992 & Increase in top corporate income tax rate from $8 \%$ to $8.25 \%$ & 9 \\
\hline MT & 1992 & Re-introduction of tax surcharge on tax liability at $2.3 \%$ rate & 1 \\
\hline MO & 1993 & $\begin{array}{l}\text { Increase in top corporate income tax rate from } 5 \% \text { to } 6.25 \% \text { and reduction in federal income } \\
\text { tax deductibility from } 100 \% \text { to } 50 \%\end{array}$ & 43 \\
\hline MT & 1993 & Increase in tax surcharge on tax liability from $2.3 \%$ to $4.7 \%$ & 1 \\
\hline DC & 1994 & Introduction of additional $2.5 \%$ surcharge on tax liability & 1 \\
\hline VT & 1997 & Increase in top corporate income tax rate from $8.25 \%$ to $9.75 \%$ & 7 \\
\hline $\mathrm{NH}$ & 1999 & Increase in top corporate income tax rate from $7 \%$ to $8 \%$ & 13 \\
\hline AL & 2001 & Increase in top corporate income tax rate from $5 \%$ to $6.5 \%$ & 20 \\
\hline $\mathrm{NH}$ & 2001 & Increase in top corporate income tax rate from $8 \%$ to $8.5 \%$ & 13 \\
\hline KS & 2002 & Increase in tax surcharge on taxable income from $3.35 \%$ to $4.5 \%$ & 23 \\
\hline $\mathrm{TN}$ & 2002 & Increase in top corporate income tax rate from $6 \%$ to $6.5 \%$ & 44 \\
\hline AR & 2003 & Introduction of $3 \%$ tax surcharge on tax liability & 15 \\
\hline CT & 2003 & Introduction of $20 \%$ tax surcharge on tax liability & 77 \\
\hline IN & 2003 & $\begin{array}{l}\text { Repeal of gross income tax (based on revenue rather than profits) and of supplemental income } \\
\text { tax; effective adjusted gross income tax rate (on profits) increased from } 7.75 \% \text { to } 8.5 \%\end{array}$ & 32 \\
\hline CT & 2004 & Increase in tax surcharge on tax liability to $25 \%$ & 76 \\
\hline NJ & 2006 & Introduction of $4 \%$ tax surcharge on tax liability & 116 \\
\hline MD & 2008 & Increase in top corporate income tax rate from $7 \%$ to $8.25 \%$ & 40 \\
\hline CT & 2009 & Introduction of $10 \%$ tax surcharge on tax liability for companies with revenues $>\$ 100 \mathrm{~m}$ & 39 \\
\hline NC & 2009 & Introduction of $3 \%$ tax surcharge on tax liability & 48 \\
\hline OR & 2009 & Increase in top corporate income tax rate from $6.6 \%$ to $7.9 \%$ & 22 \\
\hline IL & 2011 & Increase in top corporate income tax rate from $4.8 \%$ to $7 \%$ & 100 \\
\hline CT & 2012 & Unscheduled two-year extension of tax surcharge on tax liability and increase to $20 \%$ & 1 \\
\hline MI & 2012 & Increase in top corporate income tax rate from $4.95 \%$ to $6 \%$ & 6 \\
\hline
\end{tabular}




\section{Panel B. List of Tax Cuts.}

This table lists all U.S. state corporate income tax cuts in calendar years 1989-2012 affecting firms in fiscal years 1990-2011. In states with more than one tax bracket, we report the change to the top bracket. Tax changes are identified from the Tax Foundation (an abbreviated version of which is available at http://www.taxfoundation.org), the Book of the States, a search of the "Current Corporate Income Tax Developments" feature published periodically in the Journal of State Taxation, and state tax codes accessed through Lexis-Nexis.

\begin{tabular}{|c|c|c|c|}
\hline State & Year & Description & $\begin{array}{r}\text { No. of } \\
\text { affected } \\
\text { sample firms } \\
\end{array}$ \\
\hline $\mathrm{CO}$ & 1989 & Reduction in top corporate income tax rate from $5.5 \%$ to $5.4 \%$ & 68 \\
\hline WV & 1989 & Reduction in top corporate income tax rate from $9.6 \%$ to $9.45 \%$ & 4 \\
\hline AZ & 1990 & Reduction in top corporate income tax rate from $10.5 \%$ to $9.3 \%$ & 23 \\
\hline $\mathrm{CO}$ & 1990 & Reduction in top corporate income tax rate from $5.4 \%$ to $5.3 \%$ & 74 \\
\hline WV & 1990 & Reduction in top corporate income tax rate from $9.45 \%$ to $9.3 \%$ & 5 \\
\hline $\mathrm{CO}$ & 1991 & Reduction in top corporate income tax rate from $5.3 \%$ to $5.2 \%$ & 85 \\
\hline $\mathrm{MN}$ & 1991 & Reduction in the legislated tax increase of $0.4 \%$ & 117 \\
\hline MT & 1991 & Repeal of $5 \%$ tax surcharge & 2 \\
\hline WV & 1991 & Reduction in top corporate income tax rate from $9.3 \%$ to $9.15 \%$ & 6 \\
\hline $\mathrm{CO}$ & 1992 & Reduction in top corporate income tax rate from $5.2 \%$ to $5.1 \%$ & 85 \\
\hline CT & 1992 & Reduction in tax surcharge from $20 \%$ to $10 \%$ & 94 \\
\hline MO & 1992 & Reduction in top corporate income tax rate from $6.5 \%$ to $5 \%$ & 41 \\
\hline NC & 1992 & Reduction in tax surcharge from $4 \%$ to $3 \%$ & 65 \\
\hline WV & 1992 & Reduction in top corporate income tax rate from $9.15 \%$ to $9 \%$ & 4 \\
\hline $\mathrm{CO}$ & 1993 & Reduction in top corporate income tax rate from $5.1 \%$ to $5.0 \%$ & 81 \\
\hline CT & 1993 & Repeal of $10 \%$ tax surcharge & 70 \\
\hline ME & 1993 & Repeal of $10 \%$ tax surcharge & 3 \\
\hline NC & 1993 & Reduction in tax surcharge from $3 \%$ to $2 \%$ & 51 \\
\hline NE & 1993 & Repeal of $15 \%$ tax surcharge & 9 \\
\hline $\mathrm{NH}$ & 1993 & Reduction in top corporate income tax rate from $8 \%$ to $7.5 \%$ & 9 \\
\hline AZ & 1994 & Reduction in top corporate income tax rate from $9.3 \%$ to $9 \%$ & 31 \\
\hline MT & 1994 & Repeal of $4.7 \%$ tax surcharge & 1 \\
\hline NC & 1994 & Reduction in tax surcharge from $2 \%$ to $1 \%$ & 54 \\
\hline $\mathrm{NH}$ & 1994 & Reduction in top corporate income tax rate from $7.5 \%$ to $7 \%$ & 17 \\
\hline NJ & 1994 & Repeal of $0.375 \%$ tax surcharge & 154 \\
\hline PA & 1994 & Reduction in top corporate income tax rate from $12.25 \%$ to $11.99 \%$ & 135 \\
\hline RI & 1994 & Repeal of $11 \%$ tax surcharge & 9 \\
\hline CT & 1995 & Reduction in top corporate income tax rate from $11.5 \%$ to $11.25 \%$ & 87 \\
\hline DC & 1995 & $\begin{array}{l}\text { Reduction in top corporate income tax rate from } 10 \% \text { to } 9.5 \% \text { ( }+2 \text { tax surcharges at } 2.5 \% \\
\text { each) }\end{array}$ & 6 \\
\hline NC & 1995 & Repeal of $1 \%$ tax surcharge & 46 \\
\hline PA & 1995 & Reduction in top corporate income tax rate from $11.99 \%$ to $9.99 \%$ & 144 \\
\hline CT & 1996 & Reduction in top corporate income tax rate from $11.25 \%$ to $10.75 \%$ & 91 \\
\hline CA & 1997 & Reduction in top corporate income tax rate from $9.3 \%$ to $8.84 \%$ & 554 \\
\hline CT & 1997 & Reduction in top corporate income tax rate from $10.75 \%$ to $10.5 \%$ & 89 \\
\hline NC & 1997 & Reduction in top corporate income tax rate from $7.75 \%$ to $7.5 \%$ & 65 \\
\hline AZ & 1998 & Reduction in top corporate income tax rate from $9 \%$ to $8 \%$ & 44 \\
\hline $\mathrm{CT}$ & 1998 & Reduction in top corporate income tax rate from $10.5 \%$ to $9.5 \%$ & 84 \\
\hline NC & 1998 & Reduction in top corporate income tax rate from $7.5 \%$ to $7.25 \%$ & 59 \\
\hline $\mathrm{CO}$ & 1999 & Reduction in top corporate income tax rate from $5 \%$ to $4.75 \%$ & 91 \\
\hline CT & 1999 & Reduction in top corporate income tax rate from $9.5 \%$ to $8.5 \%$ & 77 \\
\hline NC & 1999 & Reduction in top corporate income tax rate from $7.25 \%$ to $7 \%$ & 46 \\
\hline NY & 1999 & Reduction in top corporate income tax rate from $9 \%$ to $8.5 \%$ & 265 \\
\hline $\mathrm{OH}$ & 1999 & Reduction in top corporate income tax rate from $8.9 \%$ to $8.5 \%$ & 132 \\
\hline $\mathrm{AZ}$ & 2000 & Reduction in top corporate income tax rate from $8 \%$ to $7.968 \%$ & 49 \\
\hline $\mathrm{CO}$ & 2000 & Reduction in top corporate income tax rate from $4.75 \%$ to $4.63 \%$ & 80 \\
\hline CT & 2000 & Reduction in top corporate income tax rate from $8.5 \%$ to $7.5 \%$ & 72 \\
\hline NC & 2000 & Reduction in top corporate income tax rate from $7 \%$ to $6.9 \%$ & 61 \\
\hline NY & 2000 & Reduction in top corporate income tax rate from $8.5 \%$ to $8 \%$ & 262 \\
\hline
\end{tabular}


AZ 2001 Reduction in top corporate income tax rate from $7.968 \%$ to $6.968 \%$

ID 2001 Reduction in top corporate income tax rate from $8 \%$ to $7.6 \%$

NY 2001 Reduction in top corporate income tax rate from 8\% to 7.5\% 244

KS 2003 Reduction in tax surcharge from $4.5 \%$ to $3.35 \% \quad 22$

ND 2004 Reduction in top corporate income tax rate from 10.5\% to 7\% 1

AR 2005 Repeal of 3\% tax surcharge 14

KY 2005 Reduction in top corporate income tax rate from $8.25 \%$ to $7 \% \quad 18$

$\mathrm{OH} 2005$ Tax reform phasing out corp. income tax while phasing in gross receipts tax over period of 599

years

VT 2006 Reduction in top corporate income tax rate from $9.75 \%$ to $8.9 \%$

NY 2007 Reduction in top corporate income tax rate from $7.5 \%$ to $7.1 \%$

VT 2007 Reduction in top corporate income tax rate from $8.9 \%$ to $8.5 \%$

WV 2007 Reduction in top corporate income tax rate from 9\% to 8.75\%

CT 2008 Repeal of 20\% tax surcharge

KS 2008 Reduction in tax surcharge from 3.35\% to 3.1\%

KY 2008 Reduction in top corporate income tax rate from 7\% to 6\% 16

KS 2009 Reduction in tax surcharge from 3.1\% to 3.05\% 13

WV 2009 Reduction in top corporate income tax rate from 8.75\% to 8.5\% 3

MA 2010 Reduction in top corporate income tax rate from 9.5\% to 8.75\% 134

NJ 2010

Repeal of $4 \%$ tax surcharge

Reduction in top corporate income tax rate from $8.75 \%$ to $8.25 \%$ 


\section{Table A.2. List of Changes in State Tax Loss Carryback/Carryforward Rules.}

\section{Panel A. List of Loss Carryback Period Increases.}

This table lists all state-level increases in the length of tax loss carryback periods affecting firms in fiscal years 1990-2011. Tax loss carryback period changes are identified from the Book of the States.

\begin{tabular}{lrlr}
\hline & & & \\
State & Year & Description & $\begin{array}{r}\text { No. of } \\
\text { affected } \\
\text { sample firms }\end{array}$ \\
\hline DC & 1991 & Increase in loss carryback period from 0 to 3 years & 7 \\
ME & 1991 & Increase in loss carryback period from 0 to 3 years & 3 \\
MS & 1992 & Increase in loss carryback period from 0 to 1 year \\
MS & 1993 & Increase in loss carryback period from 1 to 2 years & 7 \\
VT & 1993 & Increase in loss carryback period from 0 to 3 years & 7 \\
MS & 1994 & Increase in loss carryback period from 2 to 3 years & 4 \\
AL & 1995 & Increase in loss carryback period from 0 to 3 years & 6 \\
VT & 1998 & Increase in loss carryback period from 0 to 2 years & 21 \\
NY & 1999 & Increase in loss carryback period from 0 to 2 years & 8 \\
AK & 2002 & Increase in loss carryback period from 0 to 2 years & 282 \\
LA & 2002 & Increase in loss carryback period from 2 to 3 years & 2 \\
OK & 2002 & Increase in loss carryback period from 0 to 2 years & 23 \\
NH & 2005 & Increase in loss carryback period from 0 to 3 years & 23 \\
KS & 2008 & Increase in loss carryback period from 0 to 2 years & 12 \\
KS & 2011 & Increase in loss carryback period from 0 to 3 years & 12 \\
& & & 13 \\
\hline
\end{tabular}




\section{Panel B. List of Loss Carryback Period Reductions.}

This table lists all state-level reductions in the length of tax loss carryback periods affecting firms in fiscal years 1990-2011. Tax loss carryback period changes are identified from the Book of the States.

\begin{tabular}{|c|c|c|c|}
\hline State & Year & Description & $\begin{array}{r}\text { No. of } \\
\text { affected } \\
\text { sample firms }\end{array}$ \\
\hline ME & 1990 & Removal of ability to carry back losses (reduction from 3 years to 0 ) & 4 \\
\hline NM & 1991 & Removal of ability to carry back losses (reduction from 3 years to 0 ) & 10 \\
\hline RI & 1992 & Removal of ability to carry back losses (reduction from 3 years to 0 ) & 10 \\
\hline VT & 1992 & Removal of ability to carry back losses (reduction from 3 years to 0 ) & 4 \\
\hline VT & 1996 & Removal of ability to carry back losses (reduction from 3 years to 0 ) & 7 \\
\hline $\mathrm{AL}$ & 1997 & Removal of ability to carry back losses (reduction from 3 years to 0 ) & 28 \\
\hline NY & 1997 & Removal of ability to carry back losses (reduction from 3 years to 0 ) & 293 \\
\hline OK & 1997 & Removal of ability to carry back losses (reduction from 3 years to 0 ) & 33 \\
\hline AK & 1998 & Reduction in loss carryback period from 3 to 2 years & 2 \\
\hline DC & 1998 & Reduction in loss carryback period from 3 to 2 years & 4 \\
\hline $\mathrm{DE}$ & 1998 & Reduction in loss carryback period from 3 to 2 years & 11 \\
\hline GA & 1998 & Reduction in loss carryback period from 3 to 2 years & 100 \\
\hline $\mathrm{HI}$ & 1998 & Reduction in loss carryback period from 3 to 2 years & 5 \\
\hline IA & 1998 & Reduction in loss carryback period from 3 to 2 years & 18 \\
\hline IL & 1998 & Reduction in loss carryback period from 3 to 2 years & 153 \\
\hline IN & 1998 & Reduction in loss carryback period from 3 to 2 years & 43 \\
\hline KY & 1998 & Reduction in loss carryback period from 3 to 2 years & 18 \\
\hline MD & 1998 & Reduction in loss carryback period from 3 to 2 years & 51 \\
\hline $\mathrm{ME}$ & 1998 & Reduction in loss carryback period from 3 to 2 years & 7 \\
\hline MO & 1998 & Reduction in loss carryback period from 3 to 2 years & 56 \\
\hline MS & 1998 & Reduction in loss carryback period from 3 to 2 years & 11 \\
\hline ND & 1998 & Reduction in loss carryback period from 3 to 2 years & 1 \\
\hline VA & 1998 & Reduction in loss carryback period from 3 to 2 years & 79 \\
\hline WV & 1998 & Reduction in loss carryback period from 3 to 2 years & 5 \\
\hline ID & 1999 & Reduction in loss carryback period from 3 to 2 years & 9 \\
\hline DC & 2000 & Removal of ability to carry back losses (reduction from 2 years to 0 ) & 5 \\
\hline AK & 2001 & Removal of ability to carry back losses (reduction from 2 years to 0 ) & 1 \\
\hline LA & 2001 & Reduction in loss carryback period from 3 to 2 years & 24 \\
\hline ME & 2002 & Removal of ability to carry back losses (reduction from 2 years to 0 ) & 2 \\
\hline ND & 2003 & Removal of ability to carry back losses (reduction from 2 years to 0 ) & 1 \\
\hline IL & 2004 & Removal of ability to carry back losses (reduction from 2 years to 0 ) & 118 \\
\hline KY & 2006 & Removal of ability to carry back losses (reduction from 2 years to 0 ) & 17 \\
\hline VT & 2006 & Removal of ability to carry back losses (reduction from 2 years to 0 ) & 2 \\
\hline $\mathrm{NH}$ & 2008 & Removal of ability to carry back losses (reduction from 3 years to 0 ) & 7 \\
\hline IA & 2009 & Removal of ability to carry back losses (reduction from 2 years to 0 ) & 12 \\
\hline KS & 2009 & Removal of ability to carry back losses (reduction from 2 years to 0 ) & 13 \\
\hline
\end{tabular}


Panel C. List of Loss Carryforward Period Increases.

This table lists all state-level increases in the length of tax loss carryforward periods affecting firms in fiscal years 1990-2011. Tax loss carryforward period changes are identified from the Book of the States.

\begin{tabular}{|c|c|c|c|}
\hline State & Year & Description & $\begin{array}{r}\text { No. of } \\
\text { affected } \\
\text { sample firms } \\
\end{array}$ \\
\hline $\mathrm{AL}$ & 1990 & Increase in loss carryforward period from 5 to 15 years & 11 \\
\hline ID & 1990 & Increase in loss carryforward period from 10 to 15 years & 10 \\
\hline $\mathrm{OH}$ & 1990 & Increase in loss carryforward period from 5 to 15 years & 120 \\
\hline $\mathrm{TN}$ & 1991 & Increase in loss carryforward period from 7 to 15 years & 29 \\
\hline MS & 1992 & Increase in loss carryforward period from 5 to 15 years & 7 \\
\hline UT & 1993 & Increase in loss carryforward period from 5 to 15 years & 30 \\
\hline CA & 1994 & Increase in loss carryforward period from 5 to 15 years & 458 \\
\hline PA & 1995 & Increase in loss carryforward period from 0 to 2 years & 143 \\
\hline PA & 1996 & Increase in loss carryforward period from 2 to 3 years & 145 \\
\hline NM & 1997 & Increase in loss carryforward period from 0 to 5 years & 4 \\
\hline $\mathrm{TX}$ & 1997 & Increase in loss carryforward period from 0 to 5 years & 316 \\
\hline AK & 1998 & Increase in loss carryforward period from 15 to 20 years & 2 \\
\hline CA & 1998 & Increase in loss carryforward period from 4 to 5 years & 583 \\
\hline $\mathrm{CO}$ & 1998 & Increase in loss carryforward period from 15 to 20 years & 97 \\
\hline $\mathrm{DE}$ & 1998 & Increase in loss carryforward period from 15 to 20 years & 11 \\
\hline FL & 1998 & Increase in loss carryforward period from 15 to 20 years & 163 \\
\hline GA & 1998 & Increase in loss carryforward period from 15 to 20 years & 100 \\
\hline HI & 1998 & Increase in loss carryforward period from 15 to 20 years & 5 \\
\hline IA & 1998 & Increase in loss carryforward period from 15 to 20 years & 18 \\
\hline IL & 1998 & Increase in loss carryforward period from 15 to 20 years & 153 \\
\hline IN & 1998 & Increase in loss carryforward period from 15 to 20 years & 43 \\
\hline KY & 1998 & Increase in loss carryforward period from 15 to 20 years & 18 \\
\hline MD & 1998 & Increase in loss carryforward period from 15 to 20 years & 51 \\
\hline ME & 1998 & Increase in loss carryforward period from 15 to 20 years & 7 \\
\hline MO & 1998 & Increase in loss carryforward period from 15 to 20 years & 56 \\
\hline MS & 1998 & Increase in loss carryforward period from 15 to 20 years & 11 \\
\hline ND & 1998 & Increase in loss carryforward period from 15 to 20 years & 1 \\
\hline NY & 1998 & Increase in loss carryforward period from 15 to 20 years & 283 \\
\hline PA & 1998 & Increase in loss carryforward period from 3 to 10 years & 140 \\
\hline VA & 1998 & Increase in loss carryforward period from 15 to 20 years & 79 \\
\hline $\mathrm{VT}$ & 1998 & Increase in loss carryforward period from 15 to 20 years & 8 \\
\hline WV & 1998 & Increase in loss carryforward period from 15 to 20 years & 5 \\
\hline $\mathrm{DC}$ & 1999 & Increase in loss carryforward period from 15 to 20 years & 7 \\
\hline ID & 1999 & Increase in loss carryforward period from 15 to 20 years & 9 \\
\hline NC & 1999 & Increase in loss carryforward period from 5 to 15 years & 56 \\
\hline SC & 1999 & Increase in loss carryforward period from 15 to 20 years & 21 \\
\hline CA & 2000 & Increase in loss carryforward period from 5 to 10 years & 574 \\
\hline CT & 2000 & Increase in loss carryforward period from 5 to 20 years & 79 \\
\hline CA & 2001 & Increase in loss carryforward period from 10 to 20 years & 528 \\
\hline LA & 2001 & Increase in loss carryforward period from 15 to 20 years & 24 \\
\hline $\mathrm{NH}$ & 2002 & Increase in loss carryforward period from 5 to 10 years & 13 \\
\hline OK & 2002 & Increase in loss carryforward period from 15 to 20 years & 23 \\
\hline PA & 2002 & Increase in loss carryforward period from 10 to 20 years & 136 \\
\hline $\mathrm{OH}$ & 2003 & Increase in loss carryforward period from 15 to 20 years & 103 \\
\hline CA & 2008 & Increase in loss carryforward period from 10 to 20 years & 454 \\
\hline MA & 2010 & Increase in loss carryforward period from 5 to 20 years & 132 \\
\hline NJ & 2011 & Increase in loss carryforward period from 7 to 20 years & 83 \\
\hline
\end{tabular}




\section{Panel D. List of Loss Carryforward Period Reductions.}

This table lists all state-level reductions in the length of tax loss carryforward periods affecting firms in fiscal years 1990-2011. Tax loss carryforward period changes are identified from the Book of the States.

\begin{tabular}{crlr}
\hline State & Year & Description & $\begin{array}{r}\text { No. of } \\
\text { affected } \\
\text { sample firms }\end{array}$ \\
\hline NM & 1991 & Reduction in loss carryforward period from 15 to 5 years & 10 \\
PA & 1991 & Removal of ability to carry forward losses (reduction from 3 years to 0) \\
NM & 1992 & Removal of ability to carry forward losses (reduction from 5 years to 0) & 131 \\
RI & 1992 & Reduction in loss carryforward period from 15 to 5 years & 9 \\
CA & 1993 & Reduction in loss carryforward period from 15 to 5 years & 10 \\
CA & 1997 & Reduction in loss carryforward period from 15 to 4 years \\
CA & 2002 & Reduction in loss carryforward period from 20 to 10 years & 442 \\
LA & 2002 & Reduction in loss carryforward period from 20 to 15 years & 554 \\
IL & 2004 & Reduction in loss carryforward period from 20 to 12 years & 529 \\
VT & 2006 & Reduction in loss carryforward period from 20 to 10 years & 23 \\
& & & 118 \\
\end{tabular}


Table A.3. Effect of Tax Changes on Firm Risk: Alternative Standard Errors.

We repeat the tests in Table 2 with standard errors corrected for heteroskedasticity and cross-sectional and timeseries correlations using a two-way cluster at the firm and year levels (Gow, I.D., Ormazabal, G., Taylor, D.J., 2010. Correcting for cross-sectional and time-series dependence in accounting research. The Accounting Review 85, 483512). In columns 1 and 2, we use contemporaneous changes in the firm's home-state top marginal corporate income tax rate. In columns 3 and 4, we use lagged changes in the firm's home-state top marginal corporate income tax rate. Columns 5 and 6 use the contemporaneous nexus-weighted change in tax rates as defined in Eq. (2). For variable definitions and details of their construction, see Appendix B. The unit of analysis in each column is a firm-year. All specifications are estimated using OLS in first differences to remove firm fixed effects in the levels equations and include industry-by-year fixed effects to remove industry shocks. The fixed effects are not reported for brevity. Standard errors are shown in italics underneath the coefficient estimates. We use ${ }^{* * *}, * *$, and $*$ to denote significance at the $1 \%, 5 \%$, and $10 \%$ level (two-sided), respectively. Reflecting the signed nature of the predictions, the test for equal tax sensitivity (tax increase $=$-tax cut) is one-sided.

\begin{tabular}{|c|c|c|c|c|c|c|}
\hline & \multicolumn{6}{|c|}{ Change in $\log \ldots$} \\
\hline & $\begin{array}{c}\text { ROA } \\
\text { volatility } \\
(1)\end{array}$ & $\begin{array}{c}\text { ROIC } \\
\text { volatility } \\
(2)\end{array}$ & $\begin{array}{c}\text { ROA } \\
\text { volatility } \\
(3)\end{array}$ & $\begin{array}{c}\text { ROIC } \\
\text { volatility } \\
(4)\end{array}$ & $\begin{array}{c}\text { ROA } \\
\text { volatility } \\
(5)\end{array}$ & $\begin{array}{c}\text { ROIC } \\
\text { volatility } \\
(6)\end{array}$ \\
\hline magnitude of tax increase & $\begin{array}{l}-0.019^{* * *} \\
0.006\end{array}$ & $\begin{array}{l}-0.020^{* * * *} \\
0.006\end{array}$ & & & & \\
\hline magnitude of tax cut & $\begin{array}{l}0.016 \\
0.015\end{array}$ & $\begin{array}{l}0.018 \\
0.014\end{array}$ & & & & \\
\hline lagged tax increase & & & $\begin{array}{c}-0.026^{* * *} \\
0.004\end{array}$ & $\begin{array}{l}-0.019^{* * *} \\
0.004\end{array}$ & & \\
\hline lagged tax cut & & & $\begin{array}{l}0.000 \\
0.014\end{array}$ & $\begin{array}{l}0.000 \\
0.015\end{array}$ & & \\
\hline nexus-weighted tax increase & & & & & $\begin{array}{c}-0.024^{* * *} \\
0.009\end{array}$ & $\begin{array}{c}-0.032^{* * *} \\
0.010\end{array}$ \\
\hline nexus-weighted tax cut & & & & & $\begin{array}{l}0.014 \\
0.016\end{array}$ & $\begin{array}{l}0.017 \\
0.018\end{array}$ \\
\hline Change in ... & & & & & & \\
\hline GSP growth rate & $\begin{array}{c}-0.003 \\
0.002\end{array}$ & $\begin{array}{c}-0.003 \\
0.002\end{array}$ & $\begin{array}{c}-0.003 \\
0.002\end{array}$ & $\begin{array}{c}-0.003 \\
0.002\end{array}$ & $\begin{array}{c}-0.003 \\
0.002\end{array}$ & $\begin{array}{c}-0.003 \\
0.002\end{array}$ \\
\hline state unemployment rate & $\begin{array}{l}0.009 \\
0.007\end{array}$ & $\begin{array}{l}0.010 \\
0.007\end{array}$ & $\begin{array}{l}0.009 \\
0.007\end{array}$ & $\begin{array}{l}0.009 \\
0.007\end{array}$ & $\begin{array}{l}0.009 \\
0.007\end{array}$ & $\begin{array}{l}0.009 \\
0.007\end{array}$ \\
\hline Lagged change in ... & & & & & & \\
\hline log firm age & $\begin{array}{c}-0.526^{* * * *} \\
0.089\end{array}$ & $\begin{array}{c}-0.556^{* * *} \\
0.103\end{array}$ & $\begin{array}{c}-0.526^{* * *} \\
0.088\end{array}$ & $\begin{array}{c}-0.553^{* * *} \\
0.102\end{array}$ & $\begin{array}{c}-0.527^{* * *} \\
0.089\end{array}$ & $\begin{array}{c}-0.556^{* * *} \\
0.103\end{array}$ \\
\hline log firm size & $\begin{array}{c}-0.242^{* * *} \\
0.020\end{array}$ & $\begin{array}{c}-0.325^{* * *} \\
0.024\end{array}$ & $\begin{array}{c}-0.242^{* * *} \\
0.020\end{array}$ & $\begin{array}{c}-0.325^{* * *} \\
0.025\end{array}$ & $\begin{array}{c}-0.242^{* * *} \\
0.020\end{array}$ & $\begin{array}{c}-0.325^{* * *} \\
0.024\end{array}$ \\
\hline log market/book & $\begin{array}{l}0.123^{* * *} \\
0.010\end{array}$ & $\begin{array}{l}0.164^{* * *} \\
0.012\end{array}$ & $\begin{array}{l}0.121^{* * *} \\
0.010\end{array}$ & $\begin{array}{l}0.163^{* * *} \\
0.012\end{array}$ & $\begin{array}{l}0.123^{* * *} \\
0.010\end{array}$ & $\begin{array}{l}0.164^{* * *} \\
0.012\end{array}$ \\
\hline book leverage & $\begin{array}{l}-0.300^{* * *} \\
0.037\end{array}$ & $\begin{array}{l}-0.389^{* * *} \\
0.037\end{array}$ & $\begin{array}{l}-0.301^{* * *} \\
0.037\end{array}$ & $\begin{array}{c}-0.392^{* * *} \\
0.038\end{array}$ & $\begin{array}{l}-0.300^{* * *} \\
0.037\end{array}$ & $\begin{array}{c}-0.389^{* * *} \\
0.037\end{array}$ \\
\hline cash surplus & $\begin{array}{c}-0.250^{* * *} \\
0.034\end{array}$ & $\begin{array}{c}-0.253^{* * *} \\
0.038\end{array}$ & $\begin{array}{c}-0.248^{* * * *} \\
0.030\end{array}$ & $\begin{array}{c}-0.247^{* * *} \\
0.034\end{array}$ & $\begin{array}{c}-0.249^{* * * *} \\
0.034\end{array}$ & $\begin{array}{c}-0.253^{* * *} \\
0.038\end{array}$ \\
\hline loss carryforward & $\begin{array}{l}0.018 \\
0.011\end{array}$ & $\begin{array}{l}0.030^{\text {*** }} \\
0.010\end{array}$ & $\begin{array}{l}0.017 \\
0.011\end{array}$ & $\begin{array}{l}0.029^{* * *} \\
0.010\end{array}$ & $\begin{array}{l}0.018 \\
0.011\end{array}$ & $\begin{array}{l}0.030^{* * *} \\
0.010\end{array}$ \\
\hline sales growth & $\begin{array}{l}0.042^{* * * *} \\
0.012\end{array}$ & $\begin{array}{l}0.052^{* * *} \\
0.012\end{array}$ & $\begin{array}{l}0.042^{* * *} \\
0.013\end{array}$ & $\begin{array}{l}0.052^{* * *} \\
0.013\end{array}$ & $\begin{array}{l}0.042^{* * *} \\
0.012\end{array}$ & $\begin{array}{l}0.052^{* * *} \\
0.012\end{array}$ \\
\hline stock return & $\begin{array}{c}-0.047^{* * *} \\
0.007\end{array}$ & $\begin{array}{c}-0.055^{\text {*** }} \\
0.010\end{array}$ & $\begin{array}{c}-0.046^{* * *} \\
0.008\end{array}$ & $\begin{array}{c}-0.054^{\text {**** }} \\
0.010\end{array}$ & $\begin{array}{c}-0.047^{* * *} \\
0.007\end{array}$ & $\begin{array}{c}-0.055^{* * *} \\
0.010\end{array}$ \\
\hline Industry-year fixed effects & Yes & Yes & Yes & Yes & Yes & Yes \\
\hline$R^{2}$ & $21.3 \%$ & $21.0 \%$ & $21.4 \%$ & $21.1 \%$ & $21.3 \%$ & $21.0 \%$ \\
\hline Equal tax sensitivity? $(F)$ & 0.05 & 0.03 & $4.52^{* *}$ & $1.80^{*}$ & 0.48 & 0.83 \\
\hline No. of firms & 8,046 & 7,999 & 8,041 & 7,994 & 8,046 & 7,999 \\
\hline No. of observations & 64,447 & 64,221 & 64,435 & 64,200 & 64,447 & 64,221 \\
\hline
\end{tabular}




\section{Table A.4. Effect of Tax Changes on Firm Risk: Big and Small Tax Cuts.}

To investigate whether the insignificant coefficients on tax cuts reported in Table 2 are driven by the fact that tax cuts in our sample are, on average, smaller than tax increases (in absolute magnitude), we allow for a differential sensitivity to large and small tax cuts. For variable definitions and details of their construction, see Appendix B. The unit of analysis in each column is a firm-year. All specifications are estimated using OLS in first differences to remove firm fixed effects in the levels equations and include industry-by-year fixed effects to remove industry shocks. The full set of controls (as in Table 2) and fixed effects are included but not reported for brevity. Heteroskedasticity-consistent standard errors clustered at the state level are shown in italics underneath the coefficient estimates. We use $* * *, * *$, and $*$ to denote significance at the $1 \%, 5 \%$, and $10 \%$ level (two-sided), respectively.

\begin{tabular}{|c|c|c|c|c|}
\hline & \multicolumn{4}{|c|}{ Change in $\log . .}$. \\
\hline & $\begin{array}{c}R O A \\
\text { volatility } \\
(1)\end{array}$ & $\begin{array}{c}\text { ROIC } \\
\text { volatility } \\
(2)\end{array}$ & $\begin{array}{c}R O A \\
\text { volatility } \\
(3)\end{array}$ & $\begin{array}{c}\text { ROIC } \\
\text { volatility } \\
(4)\end{array}$ \\
\hline \multirow[t]{2}{*}{ magnitude of tax increase } & $-0.019^{* * *}$ & $-0.020^{* * *}$ & $-0.019^{* * *}$ & $-0.020^{* * *}$ \\
\hline & 0.007 & 0.007 & 0.007 & 0.007 \\
\hline \multirow[t]{2}{*}{ magnitude of large tax cut ( $\geq 50$ bps) } & 0.012 & 0.013 & & \\
\hline & 0.015 & 0.014 & & \\
\hline \multirow{2}{*}{ magnitude of small tax cut ( $<50$ bps) } & 0.048 & 0.054 & & \\
\hline & 0.046 & 0.051 & & \\
\hline \multirow[t]{2}{*}{ magnitude of large tax cut $(\geq 100$ bps) } & & & 0.008 & 0.008 \\
\hline & & & 0.017 & 0.014 \\
\hline \multirow[t]{2}{*}{ magnitude of small tax cut $(<100 \mathrm{bps})$} & & & 0.041 & 0.048 \\
\hline & & & 0.031 & 0.035 \\
\hline Controls & Yes & Yes & Yes & Yes \\
\hline Industry-year fixed effects & Yes & Yes & Yes & Yes \\
\hline$R^{2}$ & $21.3 \%$ & $21.0 \%$ & $21.3 \%$ & $21.0 \%$ \\
\hline No. of firms & 8,046 & 7,999 & 8,046 & 7,999 \\
\hline No. of observations & 64,447 & 64,221 & 64,447 & 64,221 \\
\hline
\end{tabular}


Table A.5. Effect of Tax Changes on Risk for Firms with Tight or Lax Covenants.

To test whether firms are constrained by their lenders from increasing risk in response to a tax cut, we use data from DealScan to measure the tightness of covenants. We include firms with zero leverage (according to Compustat) among firms that are unconstrained in this sense. Since DealScan does not track all borrowers and all types of borrowing, the sample size is reduced compared to our baseline tests. Columns 1 and 2 reestimate our Table 2 baseline specifications in the restricted sample. The remaining columns allow the effect of tax cuts to vary with two alternative measures of the restrictiveness of a firm's covenants. Specifically, for each firm-year, we compute the size-weighted average number of covenants and average slack across all loan facilities a firm has outstanding. Slack is the distance from the covenant threshold: for a covenant that sets a minimum limit, distance is computed as $\left(r^{\prime}-\right.$ $r$ )/sigma, where $r$ ' is the actual variable, $r$ is the covenant threshold, and sigma is the standard deviation of $r$; for a covenant that sets a maximum threshold, distance is calculated as $-\left(r^{\prime}-r\right) /$ sigma, where the extra negative sign is to ensure a consistent interpretation with that of the minimum type of covenant. We code firms as having few covenants if they either have zero leverage or at most one covenant (the sample median). We code firms as having high slack if they either have zero leverage or are at least one standard deviation above (below) the minimum (maximum) covenant threshold. For variable definitions and details of their construction, see Appendix B. The unit of analysis is a firm-year. The full set of controls (as in Table 2) and industry-by-year fixed effects are included but not reported for brevity. Heteroskedasticity-consistent standard errors clustered at the state level are shown in italics underneath the coefficient estimates. We use $* * *, * *$, and $*$ to denote significance at the $1 \%, 5 \%$, and $10 \%$ level (two-sided), respectively.

\begin{tabular}{|c|c|c|c|c|c|c|}
\hline & \multicolumn{6}{|c|}{ Change in log. } \\
\hline & $\begin{array}{c}\text { ROA } \\
\text { volatility } \\
(1)\end{array}$ & $\begin{array}{c}\text { ROIC } \\
\text { volatility } \\
(2)\end{array}$ & $\begin{array}{c}R O A \\
\text { volatility } \\
\text { (3) }\end{array}$ & $\begin{array}{c}\text { ROIC } \\
\text { volatility } \\
(4)\end{array}$ & $\begin{array}{c}\text { ROA } \\
\text { volatility } \\
(5)\end{array}$ & $\begin{array}{c}\text { ROIC } \\
\text { volatility } \\
(6)\end{array}$ \\
\hline magnitude of tax increase & $\begin{array}{c}-0.033^{*} \\
0.020\end{array}$ & $\begin{array}{c}-0.031^{*} \\
0.017\end{array}$ & $\begin{array}{c}-0.033^{*} \\
0.020\end{array}$ & $\begin{array}{c}-0.031^{*} \\
0.017\end{array}$ & $\begin{array}{c}-0.033^{*} \\
0.020\end{array}$ & $\begin{array}{c}-0.031^{*} \\
0.017\end{array}$ \\
\hline magnitude of tax cut & 0.034 & $0.043^{*}$ & -0.028 & -0.039 & 0.004 & 0.013 \\
\hline$\ldots \times$ few covenants & 0.021 & 0.022 & $\begin{array}{l}0.030 \\
0.087^{* *}\end{array}$ & $\begin{array}{l}0.028 \\
0.116^{* * *}\end{array}$ & 0.021 & 0.023 \\
\hline$\ldots \times$ high slack & & & 0.034 & 0.035 & $\begin{array}{l}0.060^{* *} \\
0.030\end{array}$ & $\begin{array}{l}0.060 \\
0.039\end{array}$ \\
\hline Controls & Yes & Yes & Yes & Yes & Yes & Yes \\
\hline Industry-year fixed effects & Yes & Yes & Yes & Yes & Yes & Yes \\
\hline$R^{2}$ & $32.0 \%$ & $31.0 \%$ & $32.0 \%$ & $31.0 \%$ & $32.0 \%$ & $31.0 \%$ \\
\hline No. of firms & 5,092 & 5,068 & 5,092 & 5,068 & 5,092 & 5,068 \\
\hline No. of observations & 29,712 & 29,624 & 29,712 & 29,624 & 29,712 & 29,624 \\
\hline
\end{tabular}




\section{Table A.6. Potential Cross-State Spillovers.}

One identification concern is that tax changes in one state may trigger changes in the behavior of firms in the neighboring states. To address this concern, we restrict the set of control firms to those located in states that do not neighbor the treated state. (This contrasts with Table 5, where the set of control firms is restricted to those located in neighboring states.) This reduces the sample compared to the baseline models shown in Table 2. To address concerns stemming from the fact that corporate tax changes occasionally coincide with changes in state taxes on bank profits or in investment incentive programs (i.e., tax credits for investment, R\&D, and job creation), columns 3 and 4 control explicitly for these concurrent changes. The unit of analysis in each specification is a firm-year. All specifications are estimated using OLS in first differences with industry-year fixed effects. The full set of controls (as in Table 2) and fixed effects are included but not reported for brevity. For variable definitions and details of their construction, see Appendix B. Heteroskedasticity-consistent standard errors clustered at the state level are shown in italics underneath the coefficient estimates. We use $* * *, * *$, and * to denote significance at the $1 \%, 5 \%$, and $10 \%$ level (two-sided), respectively. Reflecting the signed nature of the predictions, the test for equal tax sensitivity (tax increase $=$-tax cut) is one-sided.

\begin{tabular}{|c|c|c|c|c|}
\hline & \multicolumn{4}{|c|}{ Change in $\log \ldots$} \\
\hline & $\begin{array}{c}R O A \\
\text { volatility } \\
(1)\end{array}$ & $\begin{array}{c}\text { ROIC } \\
\text { volatility } \\
(2)\end{array}$ & $\begin{array}{c}R O A \\
\text { volatility } \\
(3)\end{array}$ & $\begin{array}{c}\text { ROIC } \\
\text { volatility } \\
(4)\end{array}$ \\
\hline \multirow[t]{2}{*}{ magnitude of tax increase } & $-0.022^{* *}$ & $-0.026^{* * *}$ & $-0.019^{* *}$ & $-0.027^{* *}$ \\
\hline & 0.010 & 0.009 & 0.009 & 0.011 \\
\hline \multirow[t]{2}{*}{ magnitude of tax cut } & 0.023 & $0.030^{*}$ & 0.007 & 0.007 \\
\hline & 0.016 & 0.017 & 0.012 & 0.013 \\
\hline \multirow{2}{*}{$\begin{array}{l}\text { Other coincident tax changes } \\
\text { increase in state tax on banks }\end{array}$} & & & & \\
\hline & & & $\begin{array}{r}-0.009 \\
0.018\end{array}$ & $\begin{array}{l}0.003 \\
0.016\end{array}$ \\
\hline \multirow{2}{*}{ cut in state tax on banks } & & & $0.044^{* * *}$ & $0.057^{* * *}$ \\
\hline & & & 0.014 & 0.021 \\
\hline \multirow[t]{2}{*}{ increase in state investment tax credits } & & & $-0.005^{* * *}$ & $-0.004^{*}$ \\
\hline & & & 0.002 & 0.002 \\
\hline \multirow{2}{*}{ cut in state investment tax credits } & & & -0.004 & 0.001 \\
\hline & & & 0.004 & 0.004 \\
\hline \multirow{2}{*}{ increase in state $R \& D$ tax credits } & & & -0.003 & -0.001 \\
\hline & & & 0.003 & 0.003 \\
\hline \multirow[t]{2}{*}{ cut in state $R \& D$ tax credits } & & & -0.006 & -0.005 \\
\hline & & & 0.004 & 0.004 \\
\hline \multirow[t]{2}{*}{ increase in state job tax credits } & & & -0.008 & -0.012 \\
\hline & & & 0.016 & 0.015 \\
\hline \multirow[t]{2}{*}{ cut in state job tax credits } & & & -0.009 & -0.008 \\
\hline & & & 0.034 & 0.036 \\
\hline Controls & Yes & Yes & Yes & Yes \\
\hline Industry-year fixed effects & Yes & Yes & Yes & Yes \\
\hline$R^{2}$ & $25.7 \%$ & $25.1 \%$ & $25.7 \%$ & $25.1 \%$ \\
\hline Equal tax sensitivity? $(F)$ & 0.01 & 0.04 & 0.66 & 1.19 \\
\hline No. of firms & 7,160 & 7,114 & 7,160 & 7,114 \\
\hline No. of observations & 40,900 & 40,751 & 40,900 & 40,751 \\
\hline
\end{tabular}




\section{Table A.7. Falsification Test.}

This table reports the results of estimating Christensen et al.’s (2016) falsification test of the potential bias induced by unobserved confounds. The test regresses the part of the outcome variable that is related to the observed determinants of the confound (here: the change in risk taking predicted from the economic and political controls included in columns 5 and 6 of Table 5) on the treatment variable (here: the change in the tax rate). A small coefficient in the falsification test, compared to the estimated treatment effect in the baseline test, suggests that the baseline treatment effect is unlikely to reflect unobserved confounds. Columns 1 and 2 present the results of the falsification test for the full sample, and columns 3 and 4 present the results for the neighboring-state sample used in Table 5. For variable definitions and details of their construction, see Appendix B. The unit of analysis in each column is a firm-year. The full set of controls (as in Table 2) and industry-by-year fixed effects are included but not reported for brevity. Columns 3 and 4 further control explicitly for other concurrent tax changes and include groupyear fixed effects, where a treated state and its neighboring states are coded as a group. Heteroskedasticityconsistent standard errors clustered at the state level are shown in italics underneath the coefficient estimates. We use ${ }^{* * *},{ }^{* *}$, and $*$ to denote significance at the $1 \%, 5 \%$, and $10 \%$ level (two-sided), respectively.

\begin{tabular}{|c|c|c|c|c|}
\hline & \multicolumn{4}{|c|}{ Change in $\log \ldots$} \\
\hline & $\begin{array}{c}R O A \\
\text { volatility } \\
(1)\end{array}$ & $\begin{array}{c}\text { ROIC } \\
\text { volatility } \\
(2)\end{array}$ & $\begin{array}{c}R O A \\
\text { volatility } \\
(3)\end{array}$ & $\begin{array}{c}\text { ROIC } \\
\text { volatility } \\
(4)\end{array}$ \\
\hline \multirow[t]{2}{*}{ magnitude of tax increase } & -0.001 & -0.001 & 0.000 & 0.002 \\
\hline & 0.001 & 0.002 & 0.002 & 0.002 \\
\hline \multirow[t]{2}{*}{ magnitude of tax cut } & -0.004 & -0.002 & -0.004 & -0.004 \\
\hline & 0.003 & 0.003 & 0.004 & 0.004 \\
\hline \multirow{2}{*}{$\begin{array}{l}\text { Other coincident tax changes } \\
\text { increase in state tax on banks }\end{array}$} & & & & \\
\hline & & & $\begin{array}{r}-0.004 \\
0.003\end{array}$ & $\begin{array}{l}-0.007^{* *} \\
0.003\end{array}$ \\
\hline \multirow[t]{2}{*}{ cut in state tax on banks } & & & 0.002 & -0.002 \\
\hline & & & 0.005 & 0.005 \\
\hline \multirow[t]{2}{*}{ increase in state investment tax credits } & & & 0.000 & 0.001 \\
\hline & & & 0.001 & 0.001 \\
\hline \multirow{2}{*}{ cut in state investment tax credits } & & & 0.000 & $0.001^{*}$ \\
\hline & & & 0.000 & 0.000 \\
\hline \multirow[t]{2}{*}{ increase in state $R \& D$ tax credits } & & & 0.000 & 0.000 \\
\hline & & & 0.001 & 0.001 \\
\hline \multirow[t]{2}{*}{ cut in state $R \& D$ tax credits } & & & 0.000 & -0.001 \\
\hline & & & 0.001 & 0.001 \\
\hline \multirow[t]{2}{*}{ increase in state job tax credits } & & & $0.005^{*}$ & $0.006^{* *}$ \\
\hline & & & 0.003 & 0.003 \\
\hline \multirow[t]{2}{*}{ cut in state job tax credits } & & & -0.002 & 0.000 \\
\hline & & & 0.011 & 0.010 \\
\hline Controls & Yes & Yes & Yes & Yes \\
\hline Industry-year fixed effects & Yes & Yes & Yes & Yes \\
\hline Group-year fixed effects & No & No & Yes & Yes \\
\hline$R^{2}$ & $42.9 \%$ & $46.8 \%$ & $69.6 \%$ & $72.2 \%$ \\
\hline No. of firms & 8,046 & 7,999 & 6,586 & 6,547 \\
\hline No. of observations & 64,447 & 64,221 & 29,613 & 29,498 \\
\hline
\end{tabular}




\section{Table A.8. Effect of Tax Changes on Operational Choices.}

Columns 1 and 2 report a variation on our Table 7 specification, restricting the set of control firms to those located in a neighboring state, as in Table 5. Columns 3 and 4 report a variation on our Table 7 specification, allowing firms' choices of operating risk in response to a tax cut to vary with their financial leverage (which proxies for constraints on risk taking imposed by lenders). As in Table 3, we code firms as having high (low) financial leverage if their book leverage at the end of the previous fiscal year is above (below) the sample median. For variable definitions and details of their construction, see Appendix B. The unit of analysis in each column is a firm-year. All specifications are estimated using OLS in first differences to remove firm fixed effects in the levels equations and include industry-by-year fixed effects to remove industry shocks. We include the same controls and fixed effects as in Table 5 or Table 7, as appropriate. These are not reported for brevity. Heteroskedasticity-consistent standard errors clustered at the state level are shown in italics underneath the coefficient estimates. We use ***, **, and * to denote significance at the $1 \%, 5 \%$, and $10 \%$ level (two-sided), respectively.

\begin{tabular}{lcccc}
\hline & \multicolumn{3}{c}{ Change in operating cycle } \\
\cline { 2 - 5 } & $(1)$ & $(2)$ & $(3)$ & $(4)$ \\
\hline \multirow{2}{*}{ magnitude of tax increase } & $-1.244^{* * *}$ & & $-1.702^{* * *}$ & \\
& 0.570 & & 0.379 & \\
magnitude of tax cut & -0.163 & & 0.632 & \\
& 1.167 & & 0.877 & \\
$\ldots \times$ low leverage & & & -1.399 & \\
& & $-2.774^{* *}$ & 1.412 & $-3.051^{* *}$ \\
nexus-weighted tax increase & & 1.321 & & 1.163 \\
& & -1.234 & & 0.815 \\
nexus-weighted tax cut & & 1.444 & & 1.690 \\
& & & & -3.019 \\
$\ldots \times$ low leverage & & & & 2.362 \\
& & & & \\
Controls & & Yes & Yes & Yes \\
Industry-year fixed effects & Yes & Yes & Yes & Yes \\
$R^{2}$ & $15.9 \%$ & $15.9 \%$ & $11.5 \%$ & $10.1 \%$ \\
No. of firms & 6,511 & 6,511 & 7,952 & 7,952 \\
No. of observations & 29,243 & 29,243 & 63,472 & 63,472 \\
& & & & \\
\hline
\end{tabular}




\section{Table A.9. Effect of Tax Changes on Acquisitions.}

We estimate OLS regressions to test whether, and by how much, firms change their M\&A activity in response to changes in state corporate income taxes. The dependent variable change in the number of acquisitions (or diversifying acquisitions) is defined as the difference between the number of acquisitions (or diversifying acquisitions) in year $t$ and the number of acquisitions (or diversifying acquisitions) in year $t-1$. The number of acquisitions (or diversifying acquisitions) is defined following Gormley and Matsa (2016). Specifically, the number of acquisitions is calculated using SDC's Mergers and Acquisitions Database after excluding acquisitions meeting any of the following criteria: (1) the ratio of the deal size to the market value of the acquirer's assets is less than 1\%; (2) the acquiring firm controlled more than $50 \%$ of the target's equity prior to the announcement date or less than $100 \%$ after the acquisition was completed; (3) the ultimate parent of the acquirer and the target are the same; (4) either the acquirer or the target is a financial firm; or (5) the deal was not completed within 1,000 days of the announcement date. The number of diversifying acquisitions is the number of acquisitions a firm undertakes for which its primary SIC industry does not coincide with any of the target firm's SIC codes. In columns 1 and 2, we use contemporaneous changes in the firm's home-state top marginal corporate income tax rate. In columns 3 and 4 , we use lagged changes in the firm's home-state top marginal corporate income tax rate. Columns 5 and 6 use the contemporaneous nexusweighted change in tax rates as defined in Eq. (2). The unit of analysis in each column is a firm-year. All specifications are estimated using OLS in first differences to remove firm fixed effects in the levels equations and include industry-by-year fixed effects to remove industry shocks. We include the same controls and fixed effects as in Table 2. These are not reported for brevity. Heteroskedasticity-consistent standard errors clustered at the state level are shown in italics underneath the coefficient estimates. We use ${ }^{* * *}, * *$, and * to denote significance at the $1 \%$, 5\%, and $10 \%$ level (two-sided), respectively.

\begin{tabular}{|c|c|c|c|c|c|c|}
\hline & \multicolumn{6}{|c|}{ Change in the number of ... } \\
\hline & $\begin{array}{c}\text { acquisitions } \\
\text { (1) }\end{array}$ & $\begin{array}{c}\text { diversifying } \\
\text { acquisitions } \\
\text { (2) }\end{array}$ & $\begin{array}{l}\text { acquisitions } \\
\text { (3) }\end{array}$ & $\begin{array}{c}\text { diversifying } \\
\text { acquisitions } \\
\text { (4) }\end{array}$ & $\begin{array}{l}\text { acquisitions } \\
\text { (5) }\end{array}$ & $\begin{array}{c}\text { diversifying } \\
\text { acquisitions } \\
\text { (6) }\end{array}$ \\
\hline \multirow[t]{2}{*}{ magnitude of tax increase } & 0.002 & 0.000 & & & & \\
\hline & 0.012 & 0.009 & & & & \\
\hline \multirow{2}{*}{ magnitude of tax cut } & 0.006 & 0.000 & & & & \\
\hline & 0.010 & 0.007 & & & & \\
\hline \multirow{2}{*}{ lagged tax increase } & & & 0.005 & 0.007 & & \\
\hline & & & 0.006 & 0.004 & & \\
\hline \multirow[t]{2}{*}{ lagged tax cut } & & & 0.019 & 0.010 & & \\
\hline & & & 0.014 & 0.010 & & \\
\hline \multirow[t]{2}{*}{ nexus-weighted tax increase } & & & & & -0.004 & -0.003 \\
\hline & & & & & 0.013 & 0.011 \\
\hline \multirow[t]{2}{*}{ nexus-weighted tax cut } & & & & & 0.015 & 0.003 \\
\hline & & & & & 0.009 & 0.007 \\
\hline Controls & Yes & Yes & Yes & Yes & Yes & Yes \\
\hline Industry-year fixed effects & Yes & Yes & Yes & Yes & Yes & Yes \\
\hline$R^{2}$ & $14.2 \%$ & $13.8 \%$ & $14.4 \%$ & $14.1 \%$ & $14.2 \%$ & $13.8 \%$ \\
\hline No. of firms & 8,077 & 8,077 & 7,931 & 7,931 & 8,077 & 8,077 \\
\hline No. of observations & 64,721 & 64,721 & 63,762 & 63,762 & 64,721 & 64,721 \\
\hline
\end{tabular}




\section{Table A.10. Effect of Tax Changes on Equity Volatility.}

We estimate OLS regressions to test whether, and by how much, firms change their equity volatility in response to changes in state corporate income taxes in their headquarter state. Column 1 models equity volatility and column 2 models deleveraged equity volatility. Equity volatility is defined as the standard deviation of monthly returns over the 12-month period ending at the fiscal year end (measured using data from CRSP). We annualize equity volatility by multiplying it by $\sqrt{12}$. Deleveraged equity volatility is defined as equity volatility times the ratio of market capitalization (Compustat items prcc $f \times c s h o$ ) to the sum of market capitalization and the book value of debt (Compustat items dlttq $+d l c q$ ). For variable definitions and details of their construction, see Appendix B. The unit of analysis in each column is a firm-year. All specifications are estimated using OLS in first differences to remove firm fixed effects in the levels equations and include industry-by-year fixed effects to remove industry shocks. The fixed effects are not reported for brevity. Heteroskedasticity-consistent standard errors clustered at the state level are shown in italics underneath the coefficient estimates. We use ${ }^{* * *}, * *$, and $*$ to denote significance at the $1 \%, 5 \%$, and $10 \%$ level (two-sided), respectively. Reflecting the signed nature of the predictions, the test for equal tax sensitivity (tax increase $=$-tax cut) is one-sided.

\begin{tabular}{|c|c|c|}
\hline & \multicolumn{2}{|c|}{ Change in $\log \ldots$} \\
\hline & $\begin{array}{c}\text { equity volatility } \\
\text { (1) }\end{array}$ & $\begin{array}{l}\text { deleveraged } \\
\text { equity volatility } \\
\text { (2) }\end{array}$ \\
\hline \multirow[t]{2}{*}{ magnitude of tax increase } & $-0.023^{* * *}$ & $-0.020^{* * *}$ \\
\hline & 0.005 & 0.006 \\
\hline \multirow[t]{2}{*}{ magnitude of tax cut } & 0.002 & -0.003 \\
\hline & 0.005 & 0.006 \\
\hline \multicolumn{3}{|l|}{ Change in ... } \\
\hline \multirow{2}{*}{ GSP growth rate } & $-0.003^{* *}$ & -0.002 \\
\hline & 0.001 & 0.001 \\
\hline \multirow[t]{2}{*}{ state unemployment rate } & $0.022^{* * *}$ & $0.025^{* * *}$ \\
\hline & 0.005 & 0.005 \\
\hline \multicolumn{3}{|l|}{ Lagged change in ... } \\
\hline log firm age & $\begin{array}{c}-0.032^{*} \\
0.018\end{array}$ & $\begin{array}{l}-0.137^{* * *} \\
0.020\end{array}$ \\
\hline \multirow[t]{2}{*}{ log firm size } & $-0.118^{* * *}$ & $-0.175^{* * *}$ \\
\hline & 0.007 & 0.010 \\
\hline \multirow[t]{2}{*}{ log market/book } & $-0.084^{* * *}$ & $-0.113^{* * *}$ \\
\hline & 0.006 & 0.008 \\
\hline \multirow[t]{2}{*}{ book leverage } & $0.167^{* * *}$ & $0.183^{* * *}$ \\
\hline & 0.026 & 0.028 \\
\hline \multirow{2}{*}{ cash surplus } & $-0.114^{* * *}$ & $-0.062^{* * *}$ \\
\hline & 0.016 & 0.015 \\
\hline \multirow{2}{*}{ loss carryforward } & $0.011^{*}$ & $0.015^{*}$ \\
\hline & 0.006 & 0.007 \\
\hline \multirow[t]{2}{*}{ sales growth } & 0.006 & $0.010^{* *}$ \\
\hline & 0.004 & 0.005 \\
\hline \multirow[t]{2}{*}{ stock return } & $-0.024^{* * *}$ & $-0.011^{* * *}$ \\
\hline & 0.004 & 0.003 \\
\hline Industry-year fixed effects & Yes & Yes \\
\hline$R^{2}$ & $25.1 \%$ & $22.4 \%$ \\
\hline Equal tax sensitivity? $(F)$ & $8.57^{* * *}$ & $6.74^{* * *}$ \\
\hline No. of firms & 7,867 & 7,865 \\
\hline No. of observations & 63,017 & 62,992 \\
\hline
\end{tabular}




\section{Table A.11. Effect of Tax Changes on Earnings Management.}

We estimate OLS regressions to test whether, and by how much, firms change their performance-matched discretionary accruals in response to state corporate income tax changes. The dependent variable change in performance-matched discretionary accruals is defined as the difference between performance-matched discretionary accruals measured at $t$ and those measured at $t-1$. We estimate performance matched discretionary accruals as total accruals minus predicted accruals, where predicted accruals is calculated using the formula: $P R \_A C C R_{i t}=\mathrm{b}_{0}+\mathrm{b}_{1} \times\left(1 / A T_{i t}\right)+\mathrm{b}_{2} \times\left(S A L E_{i t}-S A L E_{i t-1}-R E C T_{i t}+R E C T_{i t-1}\right)+\mathrm{b}_{3} \times P P E_{i t}+\mathrm{b} 4 \times R O A_{i t-1}$. The firm-year specific parameters $\mathrm{b}_{0}$ to $\mathrm{b}_{4}$ are estimated using within SIC2-industry-year regressions: $A C C R_{j t}=\mathrm{b}_{0}+\mathrm{b}_{1} \times\left(1 / A T_{j t}\right)+$ $\mathrm{b}_{2} \times\left(S A L E_{j t}-S A L E_{j t-1}\right)+\mathrm{b}_{3} \times P P E_{j t}+\mathrm{b}_{4} \times R O A_{j t-1}+$ error $_{j t}$. In estimating the parameters for firm $i$ in year $t$, the observation of firm $i$ in year $t$ is excluded from the regression. ACCR is total accruals, calculated as Compustat item $i b c$-oancf+xidoc; $A T$ is total assets (Compustat item at); SALE is total sales (Compustat item sale); RECT is accounting receivables (Compustat item rect); PPE is property, plant, and equipment (Compustat item ppegt); ROA is return on assets (Compustat item pi/at). In columns 2 and 3, we restrict the set of control firms to those located in a neighboring state, thus excluding far-away states (i.e., firms in states that neither experience a tax rate change nor border a state that does are excluded). For variable definitions and details of their construction, see Appendix B. The unit of analysis is a firm-year. All specifications are estimated using OLS in first differences to remove firm fixed effects in the levels equations and include industry-by-year fixed effects to remove industry shocks. The full set of controls (as in Table 2) and fixed effects are included but not reported for brevity. Heteroskedasticity-consistent standard errors clustered at the state level are shown in italics underneath the coefficient estimates. We use ***, **, and $*$ to denote significance at the $1 \%, 5 \%$, and $10 \%$ level (two-sided), respectively.

\begin{tabular}{|c|c|c|c|}
\hline & \multicolumn{3}{|c|}{$\begin{array}{c}\text { Change in performance-matched } \\
\text { discretionary accruals }\end{array}$} \\
\hline & (1) & $(2)$ & (3) \\
\hline \multirow[t]{2}{*}{ magnitude of tax increase } & 0.000 & -0.001 & -0.003 \\
\hline & 0.001 & 0.001 & 0.002 \\
\hline \multirow[t]{2}{*}{ magnitude of tax cut } & -0.002 & -0.004 & -0.007 \\
\hline & 0.004 & 0.006 & 0.005 \\
\hline \multirow{2}{*}{$\begin{array}{l}\text { Other coincident tax changes } \\
\text { increase in state tax on banks }\end{array}$} & & & \\
\hline & & & $\begin{array}{l}0.007^{* *} \\
0.003\end{array}$ \\
\hline \multirow[t]{2}{*}{ cut in state tax on banks } & & & 0.007 \\
\hline & & & 0.009 \\
\hline \multirow[t]{2}{*}{ increase in state investment tax credits } & & & -0.001 \\
\hline & & & 0.001 \\
\hline cut in state investment tax credits & & & $-0.001^{* *}$ \\
\hline \multirow[t]{2}{*}{ increase in state $R \& D$ tax credits } & & & 0.000 \\
\hline & & & 0.000 \\
\hline \multirow[t]{2}{*}{ cut in state $R \& D$ tax credits } & & & -0.001 \\
\hline & & & 0.001 \\
\hline \multirow[t]{2}{*}{ increase in state job tax credits } & & & -0.006 \\
\hline & & & 0.005 \\
\hline \multirow[t]{2}{*}{ cut in state job tax credits } & & & 0.002 \\
\hline & & & 0.010 \\
\hline Controls & Yes & Yes & Yes \\
\hline Industry-year fixed effects & Yes & Yes & Yes \\
\hline$R^{2}$ & $18.7 \%$ & $24.4 \%$ & $24.4 \%$ \\
\hline No. of firms & 7,090 & 5,765 & 5,765 \\
\hline No. of observations & 56,779 & 26,058 & 26,058 \\
\hline
\end{tabular}




\section{Table A.12. Alternative Cutoffs of Loss Offset Rules.}

We repeat the tests reported in Table 8 with alternative cutoffs for the loss offset rules. Columns 1 and 3 of Panel A include firms headquartered in a state that (1) does not allow losses to be carried back and (2) does not permit losses to be carried forward for more than 12 years. Columns 2 and 4 of Panel A include only the remaining sample firms. Columns 1 and 3 of Panel B include firms headquartered in a state that (1) does not allow losses to be carried back and (2) does not permit losses to be carried forward for more than 15 years. Columns 2 and 4 of Panel B include only the remaining sample firms. For variable definitions and details of their construction, see Appendix B. The unit of analysis is a firm-year. All specifications are estimated using OLS in first differences to remove firm fixed effects in the levels equations and include industry-by-year fixed effects to remove industry shocks. The full set of controls (as in Table 2) and fixed effects are included but not reported for brevity. The tests for equal tax sensitivity across columns 1 and 2 and across columns 3 and 4 are based on fully-interacted models. Reflecting the signed nature of the predictions, the tests for equal tax sensitivity are one-sided. Heteroskedasticity-consistent standard errors clustered at the state level are shown in italics underneath the coefficient estimates. We use ${ }^{* * *}, * *$, and * to denote significance at the $1 \%, 5 \%$, and $10 \%$ level (two-sided), respectively.

\section{Panel A. Alternative Carryforward Cutoff of 12 Years.}

\begin{tabular}{|c|c|c|c|c|}
\hline & \multicolumn{4}{|c|}{ Change in $\log . .}$. \\
\hline & \multicolumn{2}{|c|}{ ROA volatility } & \multicolumn{2}{|c|}{ ROIC volatility } \\
\hline & $\begin{array}{c}\text { Low loss } \\
\text { offset ability } \\
(1)\end{array}$ & $\begin{array}{c}\text { High loss } \\
\text { offset ability } \\
\text { (2) }\end{array}$ & $\begin{array}{c}\text { Low loss } \\
\text { offset ability } \\
\text { (3) }\end{array}$ & $\begin{array}{c}\text { High loss } \\
\text { offset ability } \\
\text { (4) }\end{array}$ \\
\hline \multirow[t]{2}{*}{ magnitude of tax increase } & $-0.030^{* * *}$ & -0.004 & $-0.036^{* * * *}$ & 0.014 \\
\hline & 0.010 & 0.018 & 0.013 & 0.023 \\
\hline \multirow[t]{2}{*}{ magnitude of tax cut } & 0.009 & 0.013 & 0.017 & 0.014 \\
\hline & 0.022 & 0.018 & 0.019 & 0.020 \\
\hline Controls & Yes & Yes & Yes & Yes \\
\hline Industry-year fixed effects & Yes & Yes & Yes & Yes \\
\hline$R^{2}$ & $29.8 \%$ & $27.0 \%$ & $28.7 \%$ & $26.9 \%$ \\
\hline \multicolumn{5}{|l|}{ Equal tax sensitivity? $(F)$} \\
\hline Tax increases: (1) vs. (2) or (3) vs. (4) & \multicolumn{2}{|c|}{1.41} & \multicolumn{2}{|c|}{$3.45^{* *}$} \\
\hline No. of firms & 4,383 & 5,715 & 4,365 & 5,674 \\
\hline No. of observations & 26,863 & 37,584 & 26,771 & 37,440 \\
\hline
\end{tabular}




\section{Panel B. Alternative Carryforward Cutoff of 15 Years.}

\begin{tabular}{|c|c|c|c|c|}
\hline & \multicolumn{4}{|c|}{ Change in $\log \ldots$} \\
\hline & \multicolumn{2}{|c|}{ ROA volatility } & \multicolumn{2}{|c|}{ ROIC volatility } \\
\hline & $\begin{array}{c}\text { Low loss } \\
\text { offset ability } \\
\text { (1) }\end{array}$ & $\begin{array}{c}\text { High loss } \\
\text { offset ability } \\
\text { (2) }\end{array}$ & $\begin{array}{c}\text { Low loss } \\
\text { offset ability } \\
\text { (3) }\end{array}$ & $\begin{array}{c}\text { High loss } \\
\text { offset ability } \\
\text { (4) }\end{array}$ \\
\hline \multirow{2}{*}{ magnitude of tax increase } & $-0.027^{* * *}$ & 0.018 & $-0.033^{* * *}$ & 0.049 \\
\hline & 0.008 & 0.028 & 0.010 & 0.032 \\
\hline \multirow{2}{*}{ magnitude of tax cut } & 0.014 & -0.001 & 0.020 & 0.000 \\
\hline & 0.018 & 0.021 & 0.017 & 0.023 \\
\hline Controls & Yes & Yes & Yes & Yes \\
\hline Industry-year fixed effects & Yes & Yes & Yes & Yes \\
\hline$R^{2}$ & $24.5 \%$ & $33.8 \%$ & $24.0 \%$ & $33.6 \%$ \\
\hline \multicolumn{5}{|l|}{ Equal tax sensitivity? $(F)$} \\
\hline Tax increases: (1) vs. (2) or (3) vs. (4) & \multicolumn{2}{|c|}{$2.38^{*}$} & \multicolumn{2}{|c|}{$6.22^{* * *}$} \\
\hline No. of firms & 6,088 & 4,258 & 6,063 & 4,226 \\
\hline No. of observations & 39,775 & 24,672 & 36,640 & 24,571 \\
\hline
\end{tabular}

